\title{
A nemzetségi szállásoktól a vármegyékig. Adalékok és párhuzamok Somogy megye 10-11. századi településtörténetéhez ${ }^{1}$
}

\author{
SZATLÓCZKI GÁBOR
}

e-mail: gabor.szatloczki@gmail.com

\begin{abstract}
SzATLÓCZKI, G.: From clan seats to counties. Addition and parallels to the 10-11 C settlement history of Somogy county.

Abstract: The former area and extention of $10 \mathrm{C}$. Hungarian clans was conserved most accurately in the settlement area of medieval lesser nobles and in the boundaries of episcopal districts. The early Christian civitas emerged within the settlement area of former clans and the intermediate territories dividing them (so-called: megye) from which the medieval nobiliary counties emerged during the 13. C.
\end{abstract}

Keywords: Middle ages, county, civitas, clans, gens

\section{A topográfiai vizsgálat módszerei}

Az egyházhelyes nemesek nyugat-dunántúli településterületéről írt előző tanulmányomban Somogy megye topográfiáját a fennmaradt középkori források hiányos volta miatt csak vázlatosan mutattam be. ${ }^{2} \mathrm{Az}$ azóta eltelt időben elvégzett kutatások során sokat finomodott az a szempontrendszer, ami alapján a településsávokat rekonstruálni lehet, illetve ennek tükrében szükségesé vált az értelmezési keret fogalmainak pontosítása és meghatározása is. Elsőben Zala, Veszprém és Vas megyék településsávjainak értékelése során, abból az alapfelvetésböl indultam ki, hogy az egyházhelyes nemesek alapvetően a gyepűőrök leszármazottainak tekinthetők, és ily módon a településsávjaik az ország külső és belső határait jelölik ki. Ez az elképzelés, bár a nyugati határszélen és a belső területek esetében is részben helytálló, de a településrendszer egész országot behálózó struktúrája okán összességében tévesnek bizonyult. Emiatt nem tartható az a meghatározás sem, hogy az egyházhelyes nemesek településsávjai „gyepüsávok” lennének. A nagyobb térséget érintő településtopográfiai vizsgálatok ugyanis azt mutatják, hogy az egyházhelyes nemesek falvai valójában mintegy gerincként olyan településsávok nyomvonalát jelölik ki, ahol annak már korábban is feltételezett módon a kis és köznemesek, illetve a nemzetségi eredetü törzsbirtokok is részei voltak. Mindazonáltal ettöl élesen elkülönül a telepü-

1 Jelen tanulmányomban számtalan olyan társadalomtörténeti kérdést érintek, amelyek kutatási eredményei még publikálatlanok és egy hamarosan elkészülő nagymonográfiában dolgoztam fel. Mivel azonban a tanulmányban tárgyalt jelenségek értelmezéséhez elengedhetetlen azok vázlatos ismertetése, igyekeztem a lehető legegyszerübb módon bemutatni és indokolni a nézeteimet. A témából következő számtalan részletkérdésre a könyvben fogok kitérni. A tanulmány elkészítéséhez nyújtott segítségükért, illetve észrevételeikért Molnár Istvánnak és Varga Máténak tartozom köszönettel.

2 Szatlóczki 2019b. 68-93. léssávok által határolt belső területek birtoklástörténeti eredete, miszerint ott egyházhelyes nemesek még szórványszigetként sem nagyon találhatók, valamint a birtokok túlnyomó többsége király által nemeseknek vagy egyházaknak eladományozott birtok, jellemzően nagyobb egybefüggő tartományok összessége, kevés egyéb, vélhetően adományos nemesi birtokkal. A két struktúra elkülönülése még az időközben eltelt fél évezred okozta változások ellenére is, helyenként olyannyira látványosan megmutatkozik a 15-16. századokban, hogy sok esetben komolyabb birtoktörténeti vizsgálatok nélkül is ugyanazt az eredményt kapjuk, mint a régészeti és történeti településtopográfiai vizsgálatokat követően. A jelenség magyarázata viszonylag egyszerü, mivel egyházhelyes nemesi birtokból sosem lett jobbágyok lakta tartomány és csak az egészen kisméretűek esetében fordult elő, hogy azok egy szomszédos faluba olvadtak be. Hasonlóképpen az adományos birtokokból is ritkán lett később egyházhelyes nemesi birtok, ha mégis, akkor jellemzően csak 1-2 birtokos család eredetileg is törpebirtoka vált azzá. Mindezek okán az alábbiakban az írott források alapján rekonstruált birtokszerkezetet településsávokként, míg az azt megelőző 10-11. századi állapotot a korabeli szóhasználat alapján szállássávokként (mansio) értelmezem. Az egyazon jelenségre vonatkozó kétféle elnevezés között véleményem szerint nincs ellentmondás, mivel azok a birtokszerkezet kialakulásának és későbbi használati módjának eltérő korszakait jelentik. Hasonlóképpen megtartottam a gyűrük fogalmát, mivel a belső területek gyanítható korabeli elnevezésének használata egyelőre komoly értelmezési nehézségekhez vezetne a történettudomány által jelenleg használatos fogalmak jelentése ellenében. Végezetül meg kell jegyeznem, hogy az egyházhelyes nemesek birtokai alapján felvázolt település/szállássávok pontos szélességét és kiterjedését a térképeken nem tüntettem fel, mivel ahhoz minden egyes birtokra kiterjedő birtoklástörténeti vizsgálat szükséges. A tapasztalatok okán egy 10-15 km széles sávot feltételezhetünk, melyben a 10. századi szállások létrejöttek. Ennek megfelelöen hangsúlyoznom kell, hogy a térképeken jelölt határvonalak a középkorvégi állapotot tükrözik, abból a 10. századi szállássávok nemzetségeinek és kíséreteiknek pontos szállása nem következik, mindössze arányaiban mutatják a megtelepülés vélhető földrajzi helyzetét. Továbbá külön hangsúlyoznom kell, hogy a középkori településtopográfiából következő struktúra kialakulása, avagy hozzávetőleges megszi- 
lárdulása, a felmerülő 9-10 századi előzmények széleskörü vizsgálata nélkül, jelenleg csak a 10. század közepére és utolsó harmadára keltezhető. Ennek oka, hogy nyilvánvalóan akkor is számolni kell a megtelepülésnek és az azt követő változásoknak egy hosszabbrövidebb periódusával, ha a foglalás teljesen újonnan, vagy részben megelőző szállássávok birtokbavételével történt. Ezen felül a 11-13. századok közt is számtalan változás ment végbe, melyekről írott forrás nem maradt. Az egyes nemzetségek törzsbirtokai által kijelölt, nem egyszer több 10 kilométeres szállássávi szakaszokon belül - a középkori birtokok használatának módjához hasonlóan - a nemzetségek és közvetlen kíséretük időszakos tartózkodási helye egyelőre sem a korai helynevek, sem a régészeti források alapján nem határozható meg, legfeljebb az általuk használt temetőké. A tanulmány elkészítése során - külön hivatkozás nélkül - ezúttal is Engel Pál települési adatbázisát használtam az egyházhelyes nemesek birtokainak feldolgozásához, de ahol szükségesnek tartottam, a rovásadójegyzék alapján külön is ellenőriztem, illetve kiegészítettem az adatokat. ${ }^{3} \mathrm{~A}$ térképeket úgyszintén Engel munkája nyomán magam készítettem.

\section{A somogyi egyházhelyes nemesek településtopog- ráfiája}

Somogy megye 10-11. századi településterületének rekonstrukciójához két nagyobb forráscsoport áll rendelkezésre. Elsőben az írott források, különös tekintettel, a leginkább archaikus birtokviszonyokkal és településterülettel rendelkező egyházhelyes nemesek összeírásaira, másodsorban pedig az eddig ismerté vált régészeti lelőhelyek. Somogy megye területéröl a török hódítás következtében mindössze egy olyan dikális összeírás maradt fenn 1542-ből, amely értékelhető mennyiségü adatott tartalmaz az egyházhelyes nemesekre. ${ }^{4} \mathrm{Az}$ ez évi lajstrom ugyan a későbbiekkel ellentétben még az egész megye területére kiterjedt, de már így is csak egy töredékes lenyomatát adja a középkori oklevelekből sejthető egyházhelyes települések valós számának. A 14-15. századi okleveles anyagban, különösen a határjárások és tanúkihallgatások alkalmával számos olyan egyházhelyes, vagy néhány jobbágyos nemest is feljegyeztek, akiknek utódai, illetve birtokuk az 1542-es összeírásban már nem szerepel. Mindazonáltal a töredékes adóösszeírások hiánya valamilyen mértékben a középkori oklevelekből pótolható. Szerencsés módon több olyan irat is fennmaradt, amelyben a nagyobb hatalmaskodások vizsgálata, vagy a birtokbaiktatások alkalmával a szomszédos és megyebeli nemesek sokaságát jegyezték fel. A két féle írott forrásanyag együttes használatával pedig lehetőség nyílik az egyházhelyes nemesek somogyi településsávjainak meghatározására.

3 Engel adatbázisára tételesen nem lehet hivatkozni, de annak keresőfelületén, minden forrás könnyen visszakereshető a birtok vagy családnevek szerint. Engel 2001.

4 Magyar Nemzeti Levéltár Országos Levéltára (továbbiakban MNL OL) E 158 39. kötet 11-64. folio.
Az 1542-es összeírásban 29 településen, 347 fönyi egyházhelyes nemest írtak össze, valamint további 25 birtokon mintegy 40 nemest, akinek mindössze 1 adóköteles jobbágyportája volt és vélhetően hasonlóképpen a nemesi udvarhelyén gazdálkodott. ${ }^{5}$ Mindez a középkori oklevelekben egy-egy birtokon említett, vélhetően ugyancsak egyházhelyes, vagy időlegesen 1-2 jobbágyos nemesek által lakott mintegy 78 egész vagy részbirtokkal egészíthető ki. ${ }^{6} \mathrm{~A}$ középkori Somogy megyében így hozzávetölegesen 132 településen élt egyházhelyes kisnemesség, amivel közel akkora számú közösséget alkottak, mint a 141 településen élő zalai egyházhelyesek ${ }^{7}$ (1. ábra).

A Somogy megyei egyházhelyes nemesek településeit térképre vetítve, azok a már megismert módon, mintegy $10 \mathrm{~km}$ széles, szabályos sávokat képeznek, melyek a megyén belül egymásból kiindulva több szakaszra ágaznak, és minden esetben a megye határát átlépve, a szomszédos megyékben folytatódnak. Az első belépő szakasz a Zala megyei Fenék birtok felől, Besenyőszentgyörgynél lép be Somogy megyébe, majd rögtön kétfelé válva, egyrészről a belépő fő szakasz délnek tart Terebezd-Csömpördig, majd Segesd felett éles szögben keletnek fordulva és kisebb ívet bejárva, a Kapos folyó északi oldalán az Orci patakot átlépve, Büssü után kelet felé ér Tolna megyébe. Másrészről a Besenyőszentgyörgynél elváló szakasz a Balaton korabeli déli partjával párhuzamosan egészen a Sió völgye előtt fordul ismét Tolna megyébe. A fő sávból Nemesdéd és Nemesvid körül egy kilépő másik sáv dél-nyugat felé haladva Őrtilosnál éri el a Drávát. Ebbe a sávba lép be Pogányszentpéter körül egy zalai sáv, melyről a korábbi Zala megyét feldolgozó tanulmányban magam is azt feltételeztem, hogy a Győrtől a Rába-Marcal-Zala folyók vonalában a Dunántúlt kettészelő fősáv déli szakasza. A somogyi sávok részletes feltérképezése után azonban ez csak részben igaz, mivel a fősáv valójában a Zala folyót keletről kerüli meg, majd a fentebbi módon

5 Egyházhelyes nemesi birtokok 1542-ben: Artésháza, Babóháza, Csemperd, Déd, Eszpete, Fok, Füles, Gyolcs, Kálmán, Keresztúr, Kisfalud, Kissávoly, Kisszentgyörgy, Kisszentpál, Nemeske, Sokoród, Szakácsi Szentjakab, Tamási, Zelefalva. Szakácsi és Déd esetében vélhetően a többség nem nemesi, hanem szolgálónépi eredetü. Kisnemesek (1-5 jobbágy): Arad, Balásokháza, Bodon, Csehi, Cserallya, Dombó, Felrét, Felsőlak, Felsőpácód, Gorány, Gyöngyösmelléke, Herántfalva, Nagyszög, Ótélek, Pátró, Porog, Kohány, Sávoly, Simonfalva, Szenterzsébet, Tóti, Várad, Zolat.

6 A középkori oklevelekben szereplő kisnemesek, egy részük adománybirtokos eredetű lehet. Engel Pál adatbázisában az egy birtokon említett kisnemeseket nem név szerint, hanem a „nob.” jelzővel vette fel. Somogy megyei birtokaik: Acs, Bélc, Bodgamás, Elye, Endréd, Endus, Gyojta, Hatvan, Henyz, Hetés, Illyed, Inakod, Istvánfölde, Kaposfö, Kecsefalva, Keserd, Kohány, Korpád, Kovácsi, Kovásznya, Kynkus, Lod, Mére, Rinyamellék, Sehter, Szentgyörgy, Szentmárton, Tapasz, Tarány, Tardas, Viskó, Vyznye, Zenche. MNL OL DL 5296. Babod, Berkes, Kekcse, Kiskarád DL 17101., Fejéregyház, Horvátkút DL 17688., Álcs, Gamás, Gárdony, Kék, Kisvittya, Mács, Nagyberény, Petend, Szentmihálykék, Töl DL 19840., Csepel, Csicsal, Fehéregyház, Kapoly, Lulya, Megyeri, Nezeb, Öszöd, Varang, Víz DL 50576. Csolta, Kiskomár, Kismarót DL 101234., Acsa, Baba, Csiget, Egres, Horpács, Kölked, Magyarosd, Mátésföld, Ösz, Sárpolyán, Szentkirály, Szörény, Tüttös, Zádor, Zimány DL 102538. Lásd Borsa 1998. 295., Bándi 1986. 55. Komjáthy 1973. 7.

7 Szatlóczki 2019b. 70 


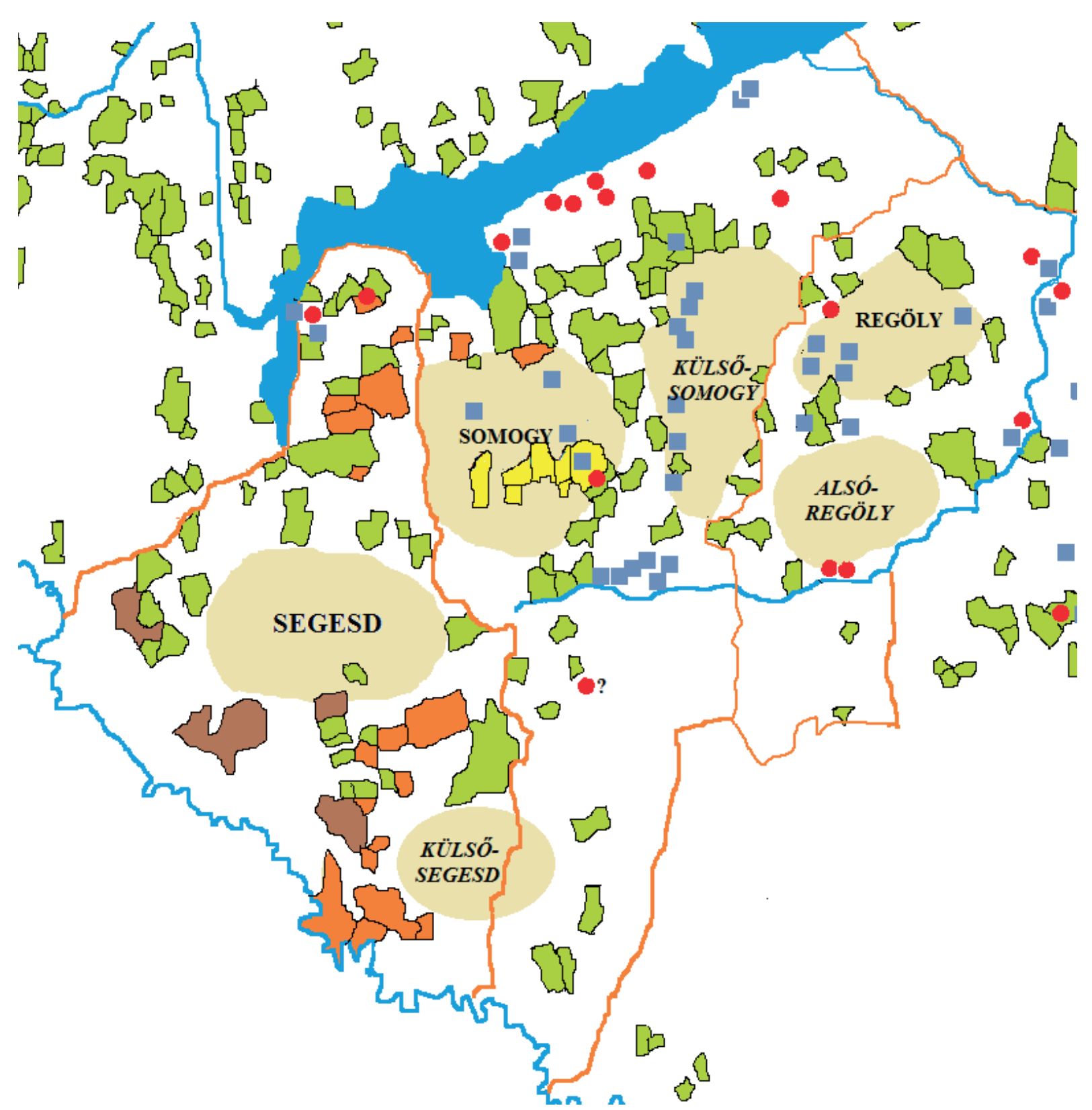

1. ábra. Somogy megye szállássávjai és belső területük a 10-11. században. (Nemzetségi birtokok (sötét); régészeti lelöhelyek, kör: szállási temető, négyzet: köznépi temető.)

Terebezdnél elfordul keletnek, illetve abból egy újabb dél-nyugati leágazás, a Zalától nyugatra, dél felé haladó sávval egyesülve éri el a Drávát. Ennek értelmezése, bár elsőre bonyolultnak hangzik, de a régészeti és történeti adatok tükrében az alábbiakban könnyen érthető lesz. További két belső sávszakasz található még Somogy megyében, elsőben a Balaton déli partja mentén és a Kapos északi oldalán futó sávokat az Orci patak nyugati oldalán, egy észak-déli tengelyű sáv köti össze. A második sáv a Kapos folyó tengelyének támaszkodva a Zselicben Ropolynál egy pontból kétfelé kiindulva, elsőben az Rinyabesenyő-Bakháza vonalon, a Rinyát átlépve Bélavár felé a Dráváig tart, másodorban pedig a Vásárosbéc, Somogyhatvan vonalon Drávatamásiig.
A térképre tekintve jól látható, hogy a településsávok lényegében négy nagyobb területre, és egy kisebb, Tolnával és Baranyával határos részre osztják Somogy megyét.

Jól megfigyelhető az is, hogy a térképen vázolt zalai és tolnai sávok összefüggésében, a Nemesvid-Kapos folyó tengely egy északi és egy déli félre választja ketté a megyét. Ennek okát azonban szükségtelen sokáig keresgélni, mivel a megye középkori egyházi és világi közigazgatásának területi beosztása gyakorlatilag egy az egyben megfeleltethető a sávok által határolt területek rendszerének. Somogy megye nagy része a középkorban a veszprémi püspökség alá tartozott, és a területén két főesperesség létrejöttéröl maradt fenn 
forrásunk. A megye két északi, településsávok által határolt belső területe egészében a somogyi, míg a két déli a segesdi főesperességhez tartozott. ${ }^{8}$ Hasonlóképpen a 16. század eleji négy szolgabírói járásnak az 1542-es rovásadójegyzékek alapján megállapítható területe, megfeleltethető a négy, településsávok által kijelölt régióknak. ${ }^{9}$

A mai Somogy megye két felének különállása jól körvonalazható a történeti forrásokból is, annak eredete írásos emlékeinkben egészen a 11. századig nyúlik vissza. Somogy megye első említését hagyományosan az 1001-ben kelt pannonhalmi alapítólevélhez köti a történetírás, amelynek feltehetően két oklevélből interpolált szövegében, az egyes szám első személyben megfogalmazott, és István királynak tulajdonított oklevélrészében szerepel. Ennek hitelét azonban némileg gyengíti, hogy Somogy megye - a korban sem ismeretlen fogalommal - csak comitatusként, azaz a 13. századtól elterjedt szóhasználattal vármegyeként, avagy ispánságként szerepel. ${ }^{10}$ Mivel az oklevél ezen része elsősorban éppen a tizedek birtoklását hivatott alátámasztani, abban a veszprémi püspökség adományleveléhez hasonlóan épphogy az oklevél kiadása idején már nyilvánvalóan létező somogyi civitas(ok) kéne, hogy szerepeljen, nem pedig a 13. századra kialakult egységes vármegye. Tizedfizetési kötelezettsége ugyanis nem az ispánságnak, hanem a birodalma alatt élő közösségnek volt. Ennek ellenére aligha van okunk Szent István adományában kételkedni, de az alapítólevél többszörösen átszerkesztett oklevélszövegei miatt, annak 11. század elejére vonatkoztatható forrásértéke óvatosan kezelendő. Somogy megye legelső egykorú említése így jelen tudásunk szerint a zselicszentjakabi apátság 1061-ben kiállított alapítólevelében maradt fenn. Ebben az apátságot gazdag adományokkal megalapító Győr nembeli Ottó, mint "Symigiensis civitatis comes" szerepel, másként a somogyi civitas ispánja. ${ }^{11}$

Amilyen korán előfordul a somogyi civitas, olyan késői a segesdi első említése, ami 1245-ből maradt fenn, már mint comitatus. Kétségkívül valóságos civitas volt, akárcsak Somogy, lévén a berényi (ma Iharosberény) hospesek 1264. évi szabadságleveléből egyértelművé válik, hogy mint „polgárok”, nem a somogyi, hanem a segesdi ispán alatt voltak kötelesek a királyi hadba vonulni, illetve annak ispáni, azaz bírói közhatalma alá tartoztak. ${ }^{12}$ Többet azonban ez alapján sem tudunk meg, mert a 13. század második felének közállapota közvetlenül nem vonatkoztatható a 10-11. századra. Emellett Segesd a 13. században kialakuló nemesi vármegyék sorába már nem lépett be, így önálló nemesi törvényszéke sem létesült, és a 15. század eleji felszámolásáig és eladományozásáig, megmaradt a királynék jószágaként, mint ispánság. Ennek oka vélhetően az a körülmény lehetett, hogy más ispánságok

\footnotetext{
8 ETE V. 454-462.

9 MNL OL E 158 39. kötet 11-64. folio.

10 Thoroczkay 2002. 257-259.

11 Kumorovitz 1964. 53

12 Pesty 1880. 214.
}

civitasaival ellentétben, Segesd területének eladományozható része, túlnyomórészt a 13 . század folyamán is megmaradt a királynék tulajdonában, így az annak településsávjaiban élő nemesek Somogy vármegye nemesi közösségébe integrálódtak.

A somogyi és segesdi civitasok ispánságának területét a már említett két főesperesség pápai tizedjegyzékekben összeírt egyházai alapján lehet rekonstruálni. ${ }^{13}$ Eszerint a somogyi főesperesség magába foglalta a Balaton déli partján lévő mindkét sávok által körülhatárolt területet, illetve meglepő módon kimaradt belőle a fő településsáv Besenyőszentgyörgy-Terebezd közötti szakasza, ami pedig a segesdi föesperességhez tartozott. Hasonlóképpen a somogyi föesperesség területe is lenyúlt délre, éppen a segesdi területeket keletröl határoló Ropoly-Drávatamási településsávot foglalva magába. Somogy és Segesd megye területe, tehát egy-egy településsávi szakasz erejéig, mintegy átkarolta egymást. Ez a jelenség azonban úgy tünik nem a gyürüs belsőterületekkel, hanem a településsávok létrejöttével és annak egymáshoz való viszonyával lehet összefüggésben, mivel az egyes területek közös településsávjai esetében hasonló jelenség szerte az országban minden szállássáv és gyűrüs belső területe, valamint korai esperessége esetében kimutatható. Így a külső-somogyi terület északi határoló sávja a Balaton déli oldalán északról átkarolja a középkori regölyi főesperességet, míg annak a Külső-Somoggyal közös településsávja pedig dél felé benyúlik a kelet-segesdi és tolnai gyürük közé. Mindezen felül akad még két olyan területe Somogy megyének, ahol mind a településtopográfia, mind a régészeti lelöhelyek üres területet jeleznek. $A z$ egyik ilyen a Sió csatorna menti részek, a másik pedig lényegében a Zselic keleti oldala. Ugyanakkor mindkét területről tudjuk, hogy a 11. század közepén már lakott volt, és ott a tihanyi, illetve a szentjakabi apátságoknak birtokot adományoznak. A két terület topográfiájának meghatározásához további kutatások szükségesek.

\section{Régészeti topográfia}

A mai Somogy megye területén előkerült honfoglalás kori leletanyag ugyan korántsem nevezhető nagynak, de ahhoz éppen elegendő, hogy a településsávok térképére vetítve értelmezhető legyen. Az un. szállási temetőkből napjainkig 6 került napvilágra, amelyekböl a Vörs-Papkert B, a Balatonújlak-Erdő-dülő, a belső-somogyi terület, míg Tengőd-Hétkútpuszta, Balatonboglár-Bereke-dűlő, Balatonboglár-kilátó u. a külső-somogyi terület szállássávjára esik. Egyetlen kivétel Somogyjád-Alkotmány Tsz. lelőhely, ami az Orci patak nyugati oldalán, a két említett területet elválasztó szállássávban került elő. Akad még további két temető, így a balatonlelle-irmapusztai, és a törökkoppány temető u.-i amelyeket a bizonytalan leletkörülményei okán nem vettem figyelembe, mivel további adatok hiányában egyelőre a pontos besorolásuk sem lehetséges. ${ }^{14}$

\footnotetext{
13 Engel 2001. A somogyi és segesdi föesperességek.
}

14 Hegyi-Varga 2015. 1-8. 
Az un. 10-11. századi nagy sírszámú szolgálói temetőkből 4 ismert a megyéből, így Fiad-Kérpuszta (388 sír), Kaposvár-Kertészet, Kaposvár 61-es elkerülő, és a Vörs-Majori-dülő. Mindezen felül ismert még 17 temető, melyek egyértelmü besorolását egyelöre nem teszi lehetővé az a körülmény, hogy ezek egyike sem lett teljesen feltárva. ${ }^{15} \mathrm{~A}$ fentebbi temetők településsávokhoz való viszonyában első ránézésre is több szembeötlő jelenség is látszik. Túl azon, hogy a mai megyét a Kapos vonalában kettéosztó fősávtól délre lévő területen, - nem számítva a délről szorosan hozzákapcsolódóan a Kapos északi oldalán előkerült köznépi temetőket - másként Segesd megye belső részein 10-11. századi régészeti lelet alig néhány került elő. Az egyetlen, de bizonytalan leletkörülményű zselickislaki lovassíron, kívül szálási temetőre utaló lelőhely nem ismert. ${ }^{16}$ Ellenben a Kapostól északra a 10. századi szállási temetők mindegyike a sávok feltételezhető területén helyezkedik el, míg a négyből három nagy 11. századi temető a körülhatárolt területek belsejében. Mivel a belső-somogyi gyürü területéröl ismert a legteljesebb 10. századi lelőhelycsoport, valamint a vélelmezhetően ősfoglaló Bő nemzetség törzsbirtokai alapján óvatosan a szállássáv társadalomszerkezetére is következtethetünk, érdemes röviden áttekinteni a gyürü régészeti és társadalomtörténeti összefüggéseit.

A belső-somogyi szállássáv területéről 3 szállási temető ismert. Elsőben a Balatonújlak-Erdő-dűlői temető mindközül kiemelkedik a gazdagságában, ahol a női sírokat nemesfém ékszerek és hajfonatkorongok jellemzik, míg a férfi sírokban mindössze lószerszámok és íászfelszerelés került elő, illetve csak egyetlen bolygatott sírban feltételezhető(!) mellékletként talán veretes öv. ${ }^{17}$ A 10 . század középső harmadára keltezett 17 síros szállási temető ugyan a mai Balatonújlak közigazgatási területén került elő, ám az attól nyugatra fekvő Erdő-dűlő területén húzódó magaslat alatt délről, a középkorban a Bő nemzetség Kulya nevű birtoka feküdt. ${ }^{18}$ Ettől dél-nyugatra a Vörs-Papkert B elnevezésü lelőhelyen az ásató régészek 35 sírt kelteztek a 10. századra. ${ }^{19} \mathrm{~A}$ férfi sírok közül négyben került elő ijászfelszerelés, amiből kettőt jelképes lovastemetkezés kísért. Az egyik lovastemetkezés nélküli sírban ónozott bronzból készült tegezt és tegezövet díszítő veretek voltak. ${ }^{20} \mathrm{~A}$ női sírokban a balatonújlakiakhoz hasonlóan nemesfémékszerek (öntött csüngőjü ezüst és bronz fülbevaló, aranyozott ezüst pitykék, préselt rozetta és ezüst lemezkarperec) kerültek elő, igaz attól jóval szerényebb összetételben és kivitelben. A harmadik szállási temető Somogyjádon ismeretes, ahol Bárdos Edit 12 sírt tárt fel, melyek szegényes mellékletekkel bírtak. ${ }^{21} \mathrm{Az}$ egyik férfisír íjmerevítő csontot és két nyílcsúcsot, míg egy női sír állatfejes ezüst karperecet és ezüst gyűrűt tartalmazott. ${ }^{22} \mathrm{~A}$ középkori Jád ugyancsak

15 Hegyi-Varga 2015. 3

16 Hegyi-Varga 2015. 2.

17 Langó-Siklósi 2013. 143-160.

18 Engel 2001. Térkép.

19 Költö-Szentpéteri 1996. 115-121.

20 Költő 1993. 433-443.

21 Bárdos 1991. 41.

22 Költö-Varga 2019. 193. a Bő nemzetség birtokaként ismert, ugyanakkor a jádi lelőhely mégsem kapcsolható a nemzetséghez, mivel az valójában a falu déli részére esik, ahol Alsójád birtoka feküdt. ${ }^{23}$

Annak ellenére, hogy a három szállási temetőből már csak a számuk alapján sem lehet messzemenő következtetéseket levonni, mégis felfedezhető bennük két azonos motívum, ami alapján megengedhető néhány óvatos megállapítás. Elsőben mindhárom temetőben a mellékleteket tartalmazó férfisírokat egyszerü fegyverzet (ij) és lószerszámos, részleges lovas temetkezés, valamint a női sírokat a temetőket létrehozó csoport feltételezhető társadalmi helyzetével arányosan gazdag nemesfém ékszeres mellékletek jellemzik. Ennek megfelelően hiányoznak a férfi sírokból az ékszerek, illetve a veretes övek, ellentétben a külső-somogyi gyürűn előkerült gazdag mellékletű magányos (Fonyód, Balatonszemes) temetkezésekkel. ${ }^{24}$ Vörsön és talán Balatonújlakon is egy-egy férfi sír, veretes mellékletet tartalmazott, amely az előbbi esetében a női sírokhoz hasonlóképpen, jellegében arányosnak tűnik a vörsi csoport temetkezésének gazdagságával.

Másodsorban a lelőhelyek szállás/településsávbeli helyzete alapján elmondható, hogy a szállásokból kialakuló középkori birtok, illetve az abból általánosságban eredő társadalmi helyzet, egyezést mutat a három szállási temető leletgazdagságából hangsúlyosan csak vélelmezhető állapottal. A legszegényebb és egyben legegyszerübb mellékletekkel bíró somogyjádi temető, a későbbi alsójádi kisnemesi birtokon került elő. A vörsi temető népe esetében viszont már joggal feltételezhető, hogy a szállássávot uraló nemzetség fegyveres kíséretének rangosabb rétegéből származókat képviseli, így a női sírokban megjelenő szerényebb kivitelü nemesfém ékszerek és a veretes íászfelszerelés alapján alighanem a somogyjádi lovasíjászokhoz hasonló csoportok alacsonyabb rangú vezetőjének, családtagjainak, fegyvereseinek és szolgálóinak temetőjét rejti. A vörsi szállás, sávbeli mérete és helyzete alapján az ősfoglalóktól leszármazó, vagy azt felváltó középkori birtokosa ugyancsak a tisztségviselő köznemesség legalsó, de már saját szolgáló familiát tartani tudó csoportjába tartozhatott. A kulyai (Balatonújlak-Erdő-dűlő) szállási temető esetében azonban már korántsem ilyen egyszerű helyhez kötött földrajzi összefüggést felvázolni. Kulya ugyan a Bő nem nemzetségi eredetű birtokai közé tartozott, de a nemzetség többi hasonló, vélhetően szállás eredetű birtokai, az egész belső-somogyi szállássáv gyűrüjén megtalálhatóak voltak. Mindazonáltal a gyűrü határoló szállássávjának körhossza a nyúlvány nélkül, mintegy 60-70 kilométert jelentett, amelyen öszszesen 17 olyan birtok feküdt, amely már a 13. század elején nemzetségi közös birtok lehetett, majd azokon a 14. század elején tettek osztályt. ${ }^{25}$ Vélhetően mind a 17 birtok nem létezett önálló szállásként a 10. században,

23 Engel 2001. Alsójád.

24 Hegyi-Varga 2015. 4-5.

25 Az I. Trepk idejében vásárolt vagy adományos birtokokat nem számolva: Lak, Kürtös, Jád, Bő, Bodrog, Hidas, Sörnye, Szentmárton, Szővécs, Kak, Lók, Léta, Szőcsény, Zsitva, Monyorókerék, Nyír, Terpec. Karácsonyi 1900. 280-283. 
lévén több esetben is feltételezhető, hogy azok egy nagyobb egységből önállósodtak a szolgálók letelepítésekor, valamint korábbi királyi adományok, vásárlások és eladások is módosíthatták a nemzetségi birtokok legkorábbi, avagy 10. századi kiterjedését. Érdekes módon különösen igaz ez Bő, Kürtös és Bodrog birtokokra, amelyek történetesen ugyan a szállássáv szélén, de már egyértelműen a belső területen feküdtek.

Miként értékelhető mindezek alapján a kulyai temető és a feltehetően ősfoglaló vagy annak birtokát megszerző Bő nemzetség kapcsolata? Gyanítható, hogy a temető a nemzetség egyes tagjainak, valamint azok fegyvereseinek és szolgálóinak nyughelyéül szolgált, ugyanakkor joggal vélelmezhető, hogy abban nem csak a nemzetség tagjai, hanem a szolgálatukban álló, a nemzetség uraságán belül - a temetkezésekben is megjelenő módon - különböző társadalmi rangot képviselő közelebbi atyafiságuk és távolabbi rokonságuk, szegődött fegyveres kíséretük némely tagja és családjuk is helyet kaphatott. Továbbá nem valószínű, hogy a szálláshelyeik között mozgó nemzetség minden tagja, akár egyszerre és egy időben a teljes családi és szolgálói körével egy helyen élt volna, főként nem huzamosabb ideig. Ebből fakadóan pedig a kulyai temető aligha képviseli a Bő nemzetség öszszes tagjának temetkezési helyét, sem időben, sem földrajzilag. Valószínübb tehát, hogy a nemzetség a szállássávon belüli szállásai közül egyszerre többet is használt lakóhelyként, akár az aktuálisan népesebbé váló család egyes tagjai között valamilyen formában megosztva. Ennek megfelelően egy nemzetség és kísérete egyszerre több, földrajzilag a gyűrü sávjában eltérő helyen is létesíthetett temetőt, illetve időben a szálláshasználati szokások függvényében egyes temetőiket felhagyhatták, helyette pedig másikat kezdhettek. Mégis egyes jobban kutatott, főként tiszántúli és felső-tisza-vidéki szállássávok esetében jól látszik, hogy az előkelő temetkezések a szállássávok egy rövidebb szakaszára koncentrálódnak (Rétköz, Szabolcs környéke, Bodrogvécs körül stb.). ${ }^{26}$ Ellenben nem valószínü ugyanez a nemzetségi uraság területén szálláshelyet foglaló közönséges fegyveresek, jellemzően lovasíjászok és tágabb rokonságuk, illetve a középréteg rangosabb, vagy kevésbé jelentős családjai és rokonságuk esetében. Mint az a jádi és vörsi temetők népe és leszármazottaik esetében is látszik, nekik a rangjuknak és szolgálatuknak megfelelő méretü és számú szállás jutott, ami jellemzően aligha lehetett nagyobb, mint a területen jelentkező középkori birtoktest. Valószínü, hogy a sok esetben csoportosan, egy-egy kisebb-nagyobb területen szállást foglaló közönséges lovasíjászok többségét az adott területen nem a családi és rokonsági kötelék, hanem a szolgálati formájuk közössége tartotta össze.

A belső-somogyi gyűrű szállássávjának régészeti leletei, illetőleg a későbbi településsáv és birtokrendszer közti kapcsolat azonban a már említett kis számú lelőhely okán, akár a véletlen műve is lehet.

26 Révész 2018. 313-319.
Éppen ezért szükséges eltérő földrajzi környezetben, más települési és birtokszerkezetben is megvizsgálni ugyanezen összefüggés esetleges meglétét. Kiváló példának ígérkezik az ország másik feléből a Körösök vidéke, ahol a szeghalmi főesperesség körül létező gyürüs szállássáv mérete hasonló nagyságrendet képvisel, mint a belső-somogyi gyürü ${ }^{27}$ (2. ábra).

A 13-14. században Körösköz ispánság néven szereplő terület nyugati határoló szállássávja Mezőtúrnál kezdődik és a Berettyó folyó nyomvonalát Bucsáig követi, onnan pedig a Füzesgyarmat-Újíráz vonalon éri el a Sebes-Körös folyót. Innen ismét nyugat felé a folyó vonalát követve, a folyómeder változásai nyomán részben annak déli oldalára is átlépve, végül Vésztő-Gyomaendrőd vonalában, a Berettyó és Körös folyók torkolatában záródik. ${ }^{28}$ Egyes szakaszain közös szállássávot képez a szolnoki, kemeji, szoboszlói, biharkeresztesi ${ }^{29}$ és békési gyürük hosszabb-rövidebb szakaszain. A Duna-Tisza közére és a Tiszántúlra jellemző módon a körösközi gyürü településsávján a dunántúlihoz képest jóval kisebb számban fordulnak elő egyházhelyes nemesi birtokok, még a kisnemesi birtokokkal együtt is, csak vázlatosan, igaz egyértelmúen jelölik a szállássáv nyomvonalát. A szállássáv ősfoglaló nemzetségének a Borsa (Barsa) nem tekinthető, akiknek nemzetségi törzsbirtokai a középkori Póhalom, Varsány, Nadány, Méhes, Süvöltő, Barsa, Kovácsi, Gyarmat, Pázmán, Kisharang, Bucsa sávban, délről és keletről, a szállássáv részeként, gyakorlatilag körülölelik a körösközi gyűrű belső területét. ${ }^{30}$ A belső terület nagy részét a középkorban a Kompolti család Ványa (ma Dévaványa) városa, illetve a Simai és a Hencidai Bacsó család adományos birtokai alkották. ${ }^{31}$ A szállássávon belül egyházhelyes nemesek éltek a Körös folyó déli oldalán a békési gyűrűvel közös sávban Halászteleken, Endrődön, Nemeskerekin, Bélmegyeren továbbá a dél-keleti és észak-keleti - a biharkeresztesi és nádudvari gyürükkel közös - szállássávban Kisteleken, Csifen, Nagyharangon, Dancsházán. Előfordultak még kisnemesek többek közt Ecsegen, Kérszigeten, Himesden, Tarcsán, Kernyén és Kolton. ${ }^{32}$ A békési gyűrűvel közös sávszakasz Vésztő környéki részén a Csolt nemzetség, míg a nádudvari gyűrűvel közös sávban pedig a Zovárd nemzetség tekinthető az ősfoglalók birtokszerző utódának. ${ }^{33}$ Megemlítendő továbbá, hogy a szolnoki gyűrü szállássávi nyúlványa azonos volt a körösközi gyürü Himesd-Ecseg szakaszával, ami ennél

27 A szeghalomi föesperesség területére a pápai tizedjegyzékek alapján Engel 2001. Főesperesség, szeghalomi. Továbbá az 1552-es összeírás alapján: Ványa, Balkány, Gyarmat, Harang, Bucsa, Károly, Nadány, Darvas, Ösvény, Mágor, Csekmő, Vésztő, Póhalom, Simasziget, Csépán, Orrod, Sima, Torda, Csudabala, Ecseg, Szeghalom, Pázmán. Schematismus 1896. 18.

28 1398-ban Szeghalom, Íráz, Csekmő, Bökény birtokok Körösköz comitatusban feküdtek. Nyilvánvalóan ez esetben egy tartományi ispánság nevéröl van szó, amely a térség tájnevét tartotta fenn. Pesty 1880. 13.

29 A terület elnevezése írott forrásokban nem maradt fenn, ezért a szállássávjai által határolt belső területtel megegyező esperesi kerület központja után nevezem meg.

30 Karácsonyi 1900. 202-213.

31 Engel 2001. Települések.

32 Engel 2001. Települések.

33 Karácsonyi 1900. 379-383. Karácsonyi 1901. 149-157. 


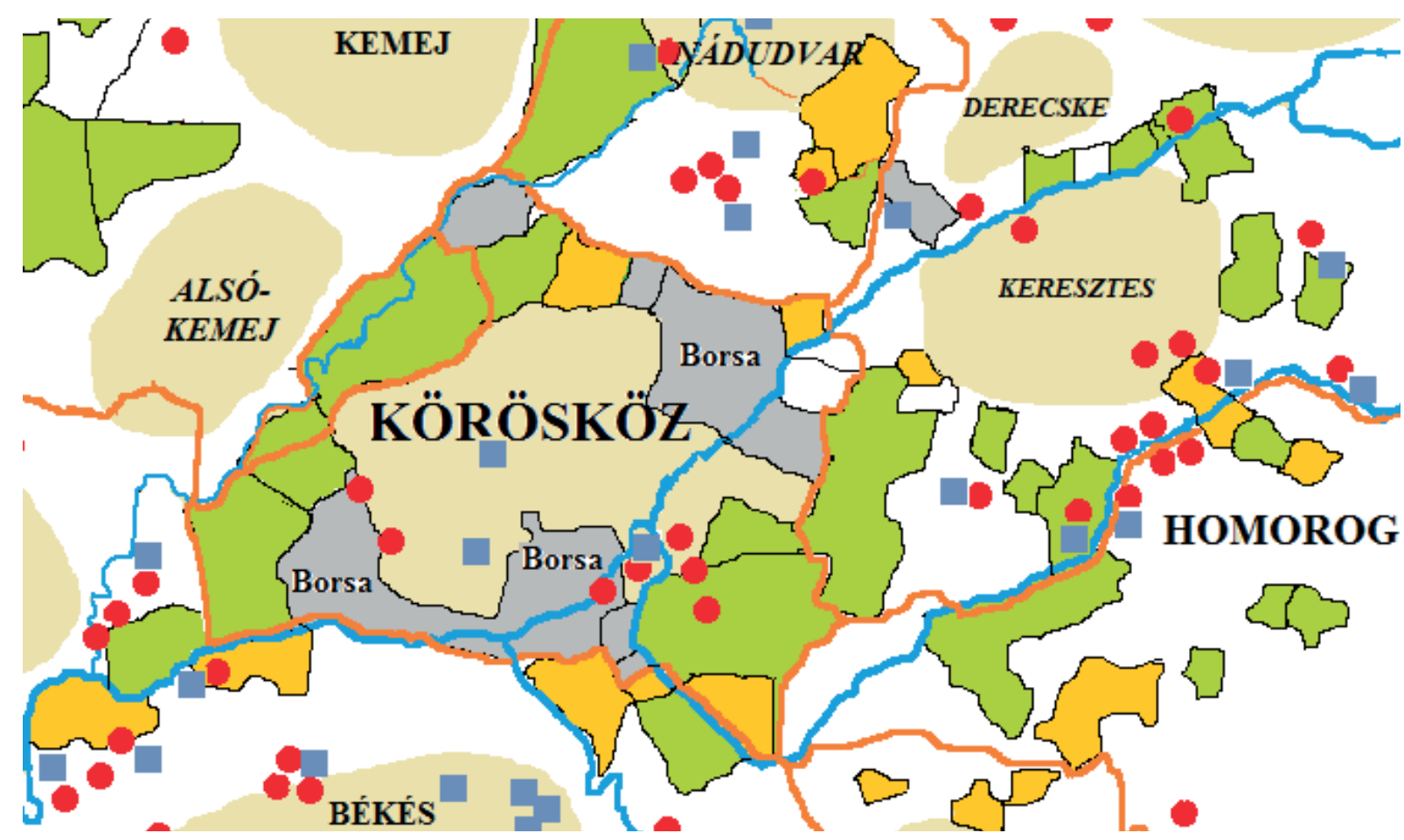

2. ábra. A körösközi szállássáv és belső területe a Borsa nemzetség birtokaival (sötét), valamint az egyházhelyes nemesek területei (világos). (Régészeti lelőhelyek, kör: szállási temető, négyzet: köznépi temetö.)

fogva a későbbiekben is annak területéhez számított. ${ }^{34}$ A régészeti lelőhelyek ugyan nem egyenletes eloszlásban követik a szállássáv egyes szakaszait, mégis a belső-somogyi lelőhelyeknél jobban megjelenítik annak belső viszonyait. Elsőben fontos megemlíteni, hogy Révész László ugyanezen területen, főként a többségében a Körös mentén elökerült lelőhelyeknek a tágabb térségen belüli egyedi jellemzői okán, maga is egy területileg jól körülhatárolt lelőhelycsoportot nevezett meg. ${ }^{35}$ Az általa Mezőtúr-Ecsegfalva-Szeghalom-Vésztő környékén felvázolt csoport egyedi hagyatékát, a csüngős kaftánveretes gazdag nők, a tarsolylemez lelete és a kis temetők jellemzői alapján különítette el. Bár felvetette a nemzetségi szállásterülettel való azonosítás lehetőséget, de „elégséges adatok” hiányában arra nem vállalkozott. A térség legkiemelkedőbb régészeti lelete, a mai Ecsegfalva-Bokroshalmon előkerült aranyozott ezüstlemezből készült palmetta mintás tarsolylemez, vélhetően a gyürü nemzetségfőjének hagyatéka. Erre utal, hogy a tarsolylemezes sír valójában nem a középkori Ecsegen, hanem attól jócskán távolabb, a Borsa nemzetség póhalomi birtokának határában került a földbe. ${ }^{36}$ A szállássáv nemzetségéhez és kíséretük rangos vezetőihez kapcsolódó temetőkön felül, szerencsés módon a körösközi gyűrün is elökerült több olyan szállási temető, amely későbbi egyházhelyes nemesi birtokon létesült. $A$

4 Szolnok megye kiterjedésére lásd Engel 2001. Térkép.

35 Révész 2018. 270-271.

36 Révész 2018. 663. Az általa közölt lelöhely térképek 57. kép (761.) szerint a mai Ecsegfalva dél-nyugati határában előkerült tarsolylemezes sír, a fekvése alapján a Borsa nemzetség Póhalom birtokára esik. Engel 2001. Póhalom. bihardancsházi temető ugyan a körösközi és nádudvari gyürük közös sávszakaszának nádidvari felén létesült, de jól jellemzi a térségből ismert szegényes szállási temetőket. A lelőhelyen Patay Pál 10 sírt tárt föl, melyből az előzetes jelentés szerint egy sírból íjászfelszerelés került elő. Mivel a temető anyaga azóta is közöletlen, mindössze csak feltételesen követeztethetünk arra, hogy a szegényes temetőt a somogyjádihoz hasonlóan egy kisebb lovasíjász csoport használta. ${ }^{37} \mathrm{~A}$ Borsa nemzetség sávbeli birtokával szemközt, a Körös folyó déli oldalán, a középkori Endrődről két hasonló temető ismert. Endrőd-Öregszőlők lelöhelyen 8 sír került elő, de mindössze egyben volt részleges lovastemetkezés és lószerszámzat. Endrőd-Szújókereszten egy 149 síros 12. század elejéig használt temető vált ismerté, amit vélhetően egy kisebb 10. századi szállási temetőre nyitottak rá. Ez utóbbiból 5 részleges lovastemetkezés került elő. A Szarvas-Rózsás-Molnár földek néven ismert lelőhely a középkori Halásztelek egyházhelyes birtokára esett. A temetőből megmentett szerény minőségü ékszerek (sodrott karperecek, préselt ezüst ruhadísz, kauricsiga, szemesgyöngy) jól ismeretek a részleges lovastemetkezéssel és íjászfelszereléssel jellemzett szegényes szállási temetőkből is. ${ }^{38}$

A térségböl egy másik szórványként előkerült tarsolylemez is ismert Bárándról, melynek eredetét a szakirodalom részben a megtalálók bizonytalan hitelű családi legendáriumra alapozva a Tisza mellöl származónak tartja. Megfontolandó azonban, hogy a tarsolylemez

37 Patay 1963. 56.

38 Révész 2018. 179-182. 
mégis a környékről származik, mivel Báránd a nádudvari gyürü déli szállássávjának azon szakaszán fekszik, amelyet a településtopográfiai és régészeti adatok alapján is a térségben jövevénynek számító Zovárd és Sártivánvecse nemzetségek, avagy ősfoglaló elődjük uralt. ${ }^{39}$ A 10. század legkiemelkedőbb régészeti leletanyagának tartott díszes tarsolylemezek azonban nem csak a körösközi és a bihari szállássávok esetében mutatnak azzal egyértelmű összefüggést, hanem a FelsőTisza vidék bodrogközi és rétközi térségében is. Régóta közismert a korszak kutatástörténetében, hogy a Felső-Tisza-vidékén különösen sok előkelő, a „nemzetségi arisztokráciától" származtatott temetkezés került napvilágra. Az ország más régióitól nagymértékben eltérő leletkoncentráció éppen ezért számos elméletet szült, miszerint a 10. század elején ebben a térségben lehetett a fejedelemség központja. A tarsolylemezes és veretes leletek előkerülésének csoportosulására már korábban felfigyelt a régészeti kutatás, míg azok földrajzi eloszlásának okára a szállássávok rendszere világít rá ${ }^{40}$ Eszerint a tarcali tarsolylemezes lelőhely a szerencsi gyürü déli szállássávján, a karosi a pataki és zempléni határoló, feltehetően az előbbi szállássávján, a bodrogvécsi a zempléni, a kenézlői, eszlári és rakamazi, tiszavasvári a szabolcsi (Nyír?), míg a bezdédi, eperjeskei és tuzséri a külső-sárvári (külső-tasi) gyürü ${ }^{41}$ szállássávján került elő. Mindezek alapján a tarsolylemezes temetkezések földrajzi csoportjai egy-egy gyűrüs terület szállássávjához kapcsolódnak, a gyakori előfordulás oka pedig a Felső-Tisza vidékére jellemző kisméretű gyürük nagy száma. Ugyanakkor a feltételezhetően nemzetségi vezetőkhöz kapcsolódó szállási temetők nem csak ebben a térségben, hanem az ismert lelőhelyek tekintetében az egész Kárpát-medencében a gyürüs szállássávok egy-egy szakaszához köthetők. Hasonlóképen csoportosulnak a rangos, méltóságjelvényekkel gazdagon ellátott temetkezések, mint a rétközberencsi, ami a sárvári (tasi) szállássávon került elő, de ugyanez elmondható a tarpai (borsovai), beregszászi (beregi), csengeri (szatmári) stb. temetkezésekről is. ${ }^{42}$

\section{A jelenség értelmezése}

A Felső-Tisza vidékén is megfigyelhető az a sajátosság, hogy az archaikus területi vonásokat követő föesperességek határai nem a későbbi vármegyékhez igazodnak, hanem a szállássávok területeivel alkotnak közös rendszert. Különöses érdekes Szabolcs vármegye topográfiai kiterjedése, ahol Zalához, Somogyhoz és Segesdhez hasonlóan éppen úgy megtalálhatóak a megyei, illetőleg a főesperességi szigetek és nyúlványok, másként Szatmár, Bihar, Bereg, és Ugocsa megyékbe

39 Révész 2018. 246., 338.

40 Révész 2018. 313-319.

41 A terület önálló elnevezésére írott forrás nem maradt fenn. Korán egybeolvadhatott a sárvári gyürűvel, bár a Tiszán átlépő szállássávi nyúlványa elkülöníthető, miként a sárvári gyűrütől is szállássáv választja el, továbbá a zempléni szállássáv átkaroló nyúlványa is elhatárolja a borsovai gyürütöl. A 10. században tehát egyértelműen önálló szállássávi gyűrű volt.

42 Révész 2018. 673-674 ékelődve is találunk egy-egy kisebb szabolcsi megye, vagy föesperességi részt. ${ }^{43}$ Mindez fordítva is igaz, így Szabolcsban is akad egy kevés rész majd mindegyik elsorolt megyéből. Az elsőre látszólag kaotikus állapotokra azonban a településsávok, a régészeti lelőhelyek, és a (fö)esperességek együttes topográfiája kézenfekvő választ ad. A középkori Szabolcs megye területén két főesperességet ismerünk, elsőben a szabolcsit, másodsorban pedig a borsovait, későbbi nevén a beregit. A szabolcsi megyenyúlványok és szigetek rendszere ugyanis elsődlegesen a két főesperesség határához igazodik, igaz még ez esetben is egymást keresztezve mindkét főesperességre több nyúlvány jut (3. ábra).

Mindazonáltal az egyházhelyes nemesek településsávjai alapján rekonstruált szállássávok felrajzolásával Szabolcs megye területén nem egy, hanem összesen 8 gyürüs belső területet jelentkezik, melyből hat, a szoboszlói, nádudvari, szabolcsi, nyíri, belső-szabolcsi és adonyi a szabolcsi főesperesség, míg a sárvári (Tassárvár) és külső-sárvári a borsovai főesperesség területére esett. ${ }^{44} \mathrm{~A}$ gyürűk azonosítása után már az egyes szabolcsi megyenyúlványok is rendszerbe sorakoznak, így jól látható, hogy a Szatmár megyébe ékelődő szakasz feltehetően a nyíri gyűrühöz, míg a béltelki gyűrü felé tartó a sárvári gyűrühöz kapcsolódott. Ugyanezt mutatja a föesperességi terület is, lévén a déli kiugrás a sárvári gyürühöz hasonlóan a borsovai föesperességhez számított, míg a szatmári beékelődés Nyírrel azonos módon vélhetően a szabolcsihoz. ${ }^{45}$ Eszerint a középkori Szabolcs megye területén a 10. században 8 gyűrü létezhetett, amelyekből feltételezhetően a 11. század folyamán 4 (a legkisebbeket nem számolva esetleg 6) esperesség jött létre. Mindebböl a 13. század végére 3 a szabolcsi, 1 viszont a borsovai föesperesség területébe integrálódott. ${ }^{46} \mathrm{Az}$ írott forrásokban mindezek közül a leggyakrabban Szabolcs és Nyír szerepel, míg Sárvárt Anonymus, a szoboszlóit pedig a Váradi Regestrum említi. ${ }^{47}$ Nyír a 14. századra Szabolcs vármegyébe olvadt a későbbi dadai járás formájában, Szoboszló és Nádudvar pedig a nádudvari járásként.

A parányi területű külső-sárvári és adonyi gyűrük mindegyike rendelkezett saját nyúlványterülettel, előbbinek a Tiszán túl Bereg megyébe, utóbbinak Bihar megyébe ékelődve. A nádudvari gyűrü nyúlványára nem maradt adat, rekonstruálásához további birtoktörténeti vizsgálatokra van szükség. Ugyanakkor mindháromban közös, hogy az írott forrásokból sem a nevüket, sem különálló egyházigazgatásukat nem

43 Engel 2001. Szabolcs megye. Az Engel Pál által közölt térképen szembetünő, hogy számtalan nyúlvány és sziget ékelődik bele a tiszántúli megyék legtöbbjébe. Így előfordulnak még megyeszigetek Bihar, Szatmár, Békés, Szolnok, Közép-Szolnok, Kraszna és Bereg megyék esetében is.

44 Engel 2001. Szabolcsi és borsovai főesperesség. A térképes adatok a pápai tizedjegyzékek alapján készültek.

45 A nyíri szállássávi nyúlványt egyedül annak Szabolcs megyéhez tartozása mutatja, mivel a 15. századra már a szatmári főesperességhez tartozott. A vajai plébános 1390-ben, mint a szatmári főesperesség száldobágyi esperese szerepelt. Gulyás 2016. 164.

46 A sárvári gyürü, mint a kisvárdai esperesség a borsovai föesperességhez tartozott. Németh 1990. 133.

47 Botka 1872. 37. 


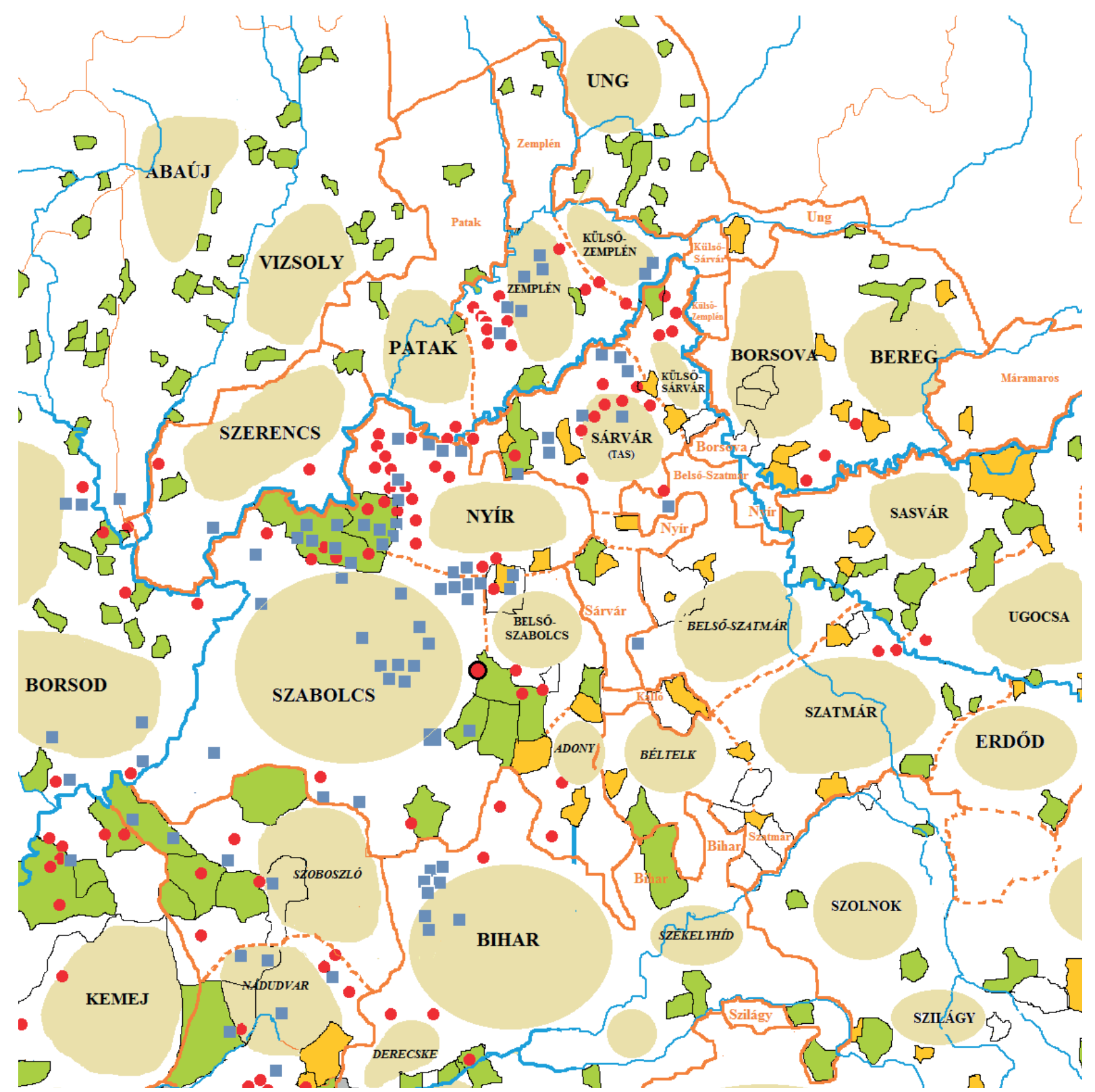

3. ábra. Felső-Tiszavidék szállássávjai és azok területe az esperességek körzethatáraival.

(Régészeti lelöhelyek, kör: szállási temető, négyzet: köznépi temető.)

ismerjük. A külső-sárvári gyürü meglétét egyedien kis mérete ellenére három dolog is bizonyítja, elsőben egy a sárváritól elhatároló egyházhelyes településsáv (Lővőpetri, Lővő, Jéke) másodsorban Borsovától a zempléni szállássáv nyúlványa és főesperessége választja el, végül pedig a Beregbe átnyúló szállássáv. Mégis vélhetően mindkét kicsi gyürü még az egyházszervezés előtt, a 10. század végén, vagy legkésőbb a föesperességek kialakításakor a 11. század végén egyesült a szomszédos gyűrűkkel. Mindebből persze csak a topográfiai azonosságok okán következne önálló civitas és korai esperesség, mégis több példára van adat a térségből, ahol az összeolvadás csak a 13. század közepén történt meg, így már az írott források is tudósítanak róluk. Ilyen volt a szomszédos Szatmár vármegye későbbi területén Erdőd, melynek gyűrűje jól azonosítható a településsávok alapján, ispánságként is említik, és civitas is szerveződhetett benne, mert 1216-ban egyszerre szerepel az ispánja, a (fö) esperese és a poroszlója. ${ }^{48}$ Ugyancsak két homályos említése maradt fenn Szoboszlónak, ahonnan esperesről és jobbágyokról értesülünk. ${ }^{49}$ Egy másik példa

48 Erdőd megyére Pesty 1880. 137-138.

49 Megjegyezendő, hogy a szakirodalom Botka Tivadar kivételével a szoboszlói főesperesség említését a Váradi Regestrum másolati hibájának tartja. Karácsonyi János meggyőzően érvelt a tévedés mellett. Németh 1990. 137. A kérdés alighanem eldönthetetlen, de ettöl függetlenül a szállássávot és területét, mind a topográfia, mind a régészeti lelőhelyek kirajzolják. 
Zemplén esete, ahol a településsávok 4 kicsi gyürüt mutatnak, melyekből három szerepel megyeként a forrásokban, illetve kettő esetében önálló esperességről is tudunk. A három gyűrü, Szerencs, Patak és Zemplén néven fordul elő egészen a 14. századig, hasonlóképpen a Szerencs megyére és nyúlványára kiterjedően említett alsó-zempléni, illetve a Zemplén megyéhez tartozó zempléni (fő)esperesség..$^{50}$ Pataki esperességről nem maradt említés, de éppen Erdőd és Szerencs esete mutatja, hogy mivel megyeként is előfordul és gyűrüt képez, vélhetően a 13. század előtt, még ha rövid ideig is, de elképzelhető, hogy saját esperességgel rendelkezett. Ezt látszik alátámasztani, hogy a 16. századi tizedkerületi beosztás szerint a szerencsi kerület pontosan lefedte az azonos nevű gyürüt, a helmeci kerület a zempléni és külső-zempléni gyürüket, továbbá a Zemplén nevű kerület a pataki gyürü területét és északi szállássávi nyúlványát. ${ }^{51}$

A legkönnyebben a szállássávok nyúlványai értelmezhetőek, lévén azok egy-egy szállássáv szakaszának részei, avagy folytatásai voltak. Mindebből az is feltételezhető, hogy azon oldali szállássáv nemzetsége uralta a közrefogott belső gyürüt, amelynek nyúlványára a területen létrehozott esperesség is kiterjedt. Másként a nyíri belső terület a déli szállássáv nemzetségének uralma alá tartozott, mivel az a sáv folytatódott keletnek, míg a sárvárival közös szállássáv már a sárvári területet uralta, lévén dél-keleti irányban a nyúlvány annak esperességéhez tartozott. Előfordult, hogy a szállássávi nyúlvány a vármegye része maradt, mint például Zalában, Somogyban, Szatmárban és Szabolcsban, de korai hovatartozását jobbára csak a szomszédos vármegyéhez csatolt (fö)esperességek megyehatárokon átlépő területe tartotta fenn. Megesett az is, hogy éppenséggel pusztán a vármegye nyúlványaként maradt fenn, és eredeti főesperességétől egy másikhoz csatolták, mint a nyíri nyúlványt. Akadtak olyan gyűrük és szállássávok, melyek már a 11. század elejére összeolvadhattak valamely szomszédjukkal, és lehettek olyanok is, ahol a szállássáv ugyan létrejött, de belső területén nem alakult esperesség és civitas sem, hanem az megmaradt királyi magán jószágnak a 12. század végéig. Ilyen lehetett a térségben például a pataki, a beregi, vagy az ugocsai gyürü. Megemlítendő még, hogy a Felső-Tisza vidékén is található olyan szállássávi gyürűs terület, melyből külön várispánság alakult, mégis a példáink tükrében további vizsgálatok szükségesek a sásvári/ugocsai, és a borsovai/beregi föesperességek azonosságának, avagy korai összeolvadásának egyértelmű meghatározásához. Erre utal a máramarosi esperességnek a későbbi Ugocsa és Bereg közé ékelődő nyúlványa, illetve az önálló gyürük, amelyek mind a négy esetben korai, és különálló területi szervezetet feltételeznek.

E sajátos esperességi területi nyúlványok az egyházhelyes nemesek településterülete mellett, minden másnál archaikusabb formában, valószínűsíthetően a 10. századi szállássávok kiterjedését őrizték meg és

50 Pesty 1880. 139-147. Pesty 1882. 574-577. Szűcs 1993 1-57. 51 Liber Sancti Johannis 2005. 29-32. eredetileg majd mindegyik belső terület rendelkezhetett önálló keresztelöegyházzal és egyházközösséggel, illetőleg ebből fakadóan saját korai civitasszal is. Önálló egyházközség ugyanis aligha alakulhatott az azt eltartó, tehát tizedfizetésre kötelezett hívek közössége, más szóval a civitas nélkül. A 11. század első felének egyházszervezése eredményeként az esperességekre épülő egyházszervezet idővel természetes úton jutott el az igazgatási rendszer első átalakításához. A növekvő számú egyházközségek okán a 11. század utolsó harmadában egy-egy archidiaconus már egyszerre több esperesség élén is állhatott, és esperességei igazgatására maga helyett vicéket, avagy vicearchidiaconusokat nevezett ki. ${ }^{52}$ Vélhetően az esperességek összevonásával egy időben, a 11. század közepére kialakult civitasrendszer igazgatásának átalakulása, avagy azok összeolvadása is megkezdődött, ezzel hozható összefüggésbe, hogy a 12. század végétöl több forrásban is következetesen már csak 72 megye szerepelt. ${ }^{53}$ Mindez azonban nem egyetlen döntést követő rövid idejü változással történhetett, hanem a megyék évszázados léptékű folyamatos, de lassú összeolvadásával. Az egyházszervezet fejlödése egészen a 13. század közepéig eltartott, lévén még akkor is előfordult, hogy az egyik gyürű egyházai felett már csak vice, a másik felett pedig még önmagában archidiaconus állt. ${ }^{54} \mathrm{Az}$ un. főesperességek - valójában archidiaconatusok és vicariaik - területi igazgatási struktúrája végül a 14 . század elejére szilárdult meg.

A szállássávok rendszere tehát úgy tủnik nem csak, hogy mintául szolgált István király és utódai számára a keresztény egyház és állam létrehozásakor, hanem egyenesen a 10. századi szállássávokon és belső területükön szervezeték meg az egyes civitasokat és korai esperességeket (archidiaconatus), illetőleg nagyobb igazgatási egységként idővel a püspökségeket is ahhoz igazította. ${ }^{55} \mathrm{~A}$ tiszántúli és dunántúli példák alapján az látszik, hogy a 11-13. századi írott forrásokban megyeként, hol konkrét értelemben comitatusként, azaz ispánságként, vagy közösségként, azaz civitasként, hol pedig általános értelemben provinciaként, azaz tar-

52 A keresztelő egyházak fejlődésére és a föesperességek kialakulására lásd Kristó 1988. 347-348.

53 Pesty Frigyes aprólékosan összeszedte mindazon forráshelyeket, ahol vármegyéket, különösen 72-öt soroltak fel. Pesty 1880. 3-58.

54 Például Szoboszló és Erdőd élén még archidiaconust említenek, ami csak úgy lehetséges, hogy a föesperes vagy az eredeti esperességéből igazgatta a többi vicariát, és arról is nevezték, tehát még nem feltétlenül költözött be a káptalanba kanonokként, vagy még nem szilárdultak meg a föesperességi területi igazgatási egységek és neveik.

55 A nemzetségi szállásterületből kialakuló vármegyék elméletét először Györffy György dolgozta ki, azonban a megyék esetében azok 13. századi területéből indult ki, míg a szállássávok esetében csak a bizonytalanul rekonstruálható nemzetségi birtokokat vette alapul. Felvetése ugyan helytálló, de az általa leírt módon a 10. századi szállásterület csak nyomokban és számtalan hibával rekonstruálható. A szállássávok pontos meghatározása nélkül pedig a régészeti lelőhelyekkel alig összeegyeztethető. Györffy ugyanis nem foglalkozott részletesen az egyházi és világi igazgatás területi rendszerével, továbbá nem vizsgálta az egyházhelyes nemesek településtopográfiáját sem. Elmélete a későbbi számos felvetés hatására sokat módosult, így leginkább annak első közlése tekinthető mérvadónak. Györffy 1959. 16-36. 
tományként szerepelő árpád-kori megyék területe nem a 14. századra kialakuló nemesi vármegyékre aprózódott fel, hanem éppen fordítva történhetett. ${ }^{56}$ Vélelmezhetően a nemesi vármegyék jöttek létre a 10. századi szállássávok uraságainak, és az azok által határolt belső területeken alapított korai civitasok rendszerének összeolvadásából, mégpedig korántsem szabályszerü módon és mintegy három évszázados folyamatos fejlődéssel. Mindazonáltal amíg a 11. században létrejött ispánságok (comitatusok) a szállássávok és a régészeti lelőhelyek topográfiája alapján a 10. századból folytonosan eredeztethetők, addig a ráépülő esperességek igazgatási egysége, illetve a civitasok intézménye a kereszténység felvételével jól keltezhetően már egyértelműen István király és utódai alkotása volt. Az ellentmondás éppen ebben rejlik, lévén történetírásunk a korszak civitas fogalmát, mintegy történettudományi müszóként vármegye és város értelemben használja, másként különösképpen a veszprémi püspökség adományleveléböl kiindulva, egyszerre vármegye és vár(!) jelentéssel is. ${ }^{57} \mathrm{~A}$ civitas szónak és mögöttes fogalmának azonban sohasem volt se „vármegye”, se vár jelentése, míg helyrajzi értelemben vett városként is csak egyszerü képzettársításként használták a forrásainkban, méghozzá a kor jellemző gondolkodásmódja szerint, akkor is a város közössége fogalmából levezetve. Legjobb példa erre Verbőci, aki a Hármaskönyvében maga is két külön fogalomként határozta meg a civitas jelentését. Elsődlegesen közösség értelemben helyesen, úgymint: „... Azért értvén, hogy a civitast mondják, úgymint polgároknak egyességét, minthogy ott népeknek sokasága [vagyon] egy helybe gyűlve." Másodsorban pedig a magyar „váras” szó korai alapjelentéséből (körülkerített hely) elmagyarázva egyszerü helyrajzi képzettársításként: „Vagyon pedig a város, házaknak és utcáknak sokasága, a szükséges falakkal és oltalmakkal körülkerített, jó és tisztességes életre [való] szabadságokkal." ${ }^{8}$ Hogy tulajdonképpen mit is jelentett a civitas valójában, azt még 1603-ban Kolozsváron is jól tudták, és le is jegyezték a város magyar nyelvű rendtartásában: „... mely városi rendet ${ }^{59}$ az benne valóknak egyességéről neveztenek civitasnak, azért hogy egy arányú törvénnyel élnének és egy arányú méltósággal bírják egymást”. ${ }^{60}$ Egyszerübben összefoglalva, a magyarul körülkerített helyet jelentő várost, a benne élő polgárok egyességéröl, a közösségröl nevezték latinul civitasnak!

Megfejtésünk azonban itt egy újabb történettudományi műszóba ütközik, mégpedig a polgár fogalmába. A polgár, latinul a civis alatt a történetírásunk ugyanis

56 Az árpád kori nagy területü ősmegyék elméletére lásd többek közt: Kristó 1988. 199., újabb összefoglalásként Zsoldos 2010. 5-14.

57 Visegrád példáján várként értelmezve: „Azt illetően, hogy az oklevél, amikor a felsorolt várak „összes határait és területét” emlegeti, voltaképpen a vármegyének nevezett intézményt írja körül, teljes az egyetértés a magyar történetírásban." Zsoldos 1998. 1., Úrhida, mint várispánság és vár, a civitas szó jelentéséből levezetve. Zsoldos 2010. 7

58 TRIPARTITUM 1611. 463-464.

59 Polgárság.

60 Corpus Statutorum I. 262. a szabad királyi városok polgárjoggal rendelkező lakóit, és sokszor teljesen anakronisztikus módon, tágabb értelemben az azzal nem rendelkező, de ott élők csoportját is érti. ${ }^{61} \mathrm{~A}$ polgár kifejezése a középkori és különösen a 16. század eleji magyar nyelvű forrásainkban azonban oly gyakran és széles körben előfordul, mind a falvak (villa), mind a városok (oppidum) lakosságára értve, illetve a közösségek tagjaira önmaguk meghatározásaként, hogy a történetírás leginkább a parasztéhoz hasonló általános meghatározásként használja és érti. Valójában azonban a polgár fogalma nagyon is konkrét tartalommal és jogviszonnyal bírt, hovatovább az egyik legfontosabb társadalmi jogállást jelentette, amellyel a magán és egyházi uraságok, ispánságok és vártartományok népének csak egy szűk rétege rendelkezett. Mielőtt azonban erről szó esne, érdemes visszakanyarodnunk Szent István korához, mégpedig ezúttal a 16. század elején alkotó Karthauzi Névtelen magyar nyelvü tolmácsolásában. ${ }^{62}$ István király hadjáratai kapcsán ugyanis arról írt, hogy: „az nagy nyereségből, nagy sok szentegyházat és kalastromokat rakatatta ez országban ... kiket kilemb kilemb városokkal, valálokkal és kiülbelöl való szépségökkel megerőssöjtvén ...". E sorokat olvasva immáron harmadszor akadunk el, most éppenséggel nem egy újabb félreértelmezett történettudományi müszóban, hanem egy méltatlanul elfeledett jogintézményben, mégpedig a magyarul valálnak mondott birtokközösség ősi fogalmában. Ennek megértéséhez elsőben röviden meg kell határoznunk a valál fogalmát. A valál szó etimológiai értelme szerint, azon emberek közössége volt, akik egy possesio területén a földet magukénak vallották, másként annak nemcsak az ingó (használati), hanem az ingatlan igazságát is bírták. ${ }^{63}$ Bár a 16 . század előttről is sok példa maradt fenn ennek megfejtésére, azonban a források egyoldalúsága miatt a legegyszerübb a 16. századi magyar nyelvű forrásbőséget felhasználva meghatározni a valál, továbbá azon keresztül egyúttal a polgár fogalmát is. A valál intézménye ugyanis szerte az országban előfordult és egészen a 19. század közepéig változatlan formában fennmaradt, igaz a 16. századtól leggyakrabban már csak, mint község, város, vagy falu szavakkal írva, de mindig egy jól körülírt szűkebb csoport közössége értelmében használták. ${ }^{64} \mathrm{~A}$ valált latinul villanak írták, ami szó szerint a gazdálkodás egységeként majorságot jelentett, más szóval olyan helyet, ahol a falubeli letelepült ülések/szállások majorsága állt. ${ }^{65} \mathrm{~A}$ valál, másként a villabeli polgárok birtoklásának esetleges megszúnése után a megmaradó lakott vagy lakatlan településmaradványt a 13-14. századhoz hasonlóan

61 Legújabban Győr városának polgárságáról készített adattárba a szerzők szinte minden győri említésű személyt felvettek, így az adattárban megtévesztő módon rengeteg olyan személy szerepel, aki nem győri, vagy lakosként nem polgár. Az adattár elötanulmányában a polgár szó több helyütt is bizonytalanul idézőjelben szerepel. Horváth-Nemes-Vajk 2019. 153-196.

62 Karthauzi 1859. 15

63 TEsz III. 1077.

64 Budenz 1874. 291-292., Takáts 1906. 76

65 Pápai 1708. 608 
egyszerűen latinul praediumnak, a használat módjától függően pedig magyarul teleknek, majorságnak vagy pusztafalunak nevezték. A korabeli zavaró általánosítás ellenére, világosan kitünik, hogy a valál azon személyek közössége volt, akik az adott településen üléssel, latinul sessioval bírtak, függetlenül attól, hogy ahhoz tartottak-e jobbágyhelyet (sessio iobagionalis), vagy átmenetileg, esetleg tartósan az ülésüket jobbágyi hely hiányában zsellér módra élték. A közös nevező minden esetben a sessio birtoklásának ténye volt, melyből a szolgálat módjától függetlenül a közösségen belüli jogok eredtek. Olyannyira, hogy szép számmal akadtak városok és falvak, mint a Sopron megyei Kapu oppiduma, ahol a 16. században egyetlen jobbágy sem élt, mivel művelhető föld híján az összes sessiobirtokos - akiket egyébiránt polgárnak neveztek és 30-an (!) voltak - zsellér módra szolgált. ${ }^{66} \mathrm{~A}$ forrásokból az is egyértelműen kitünik, hogy a valál közösségében például bíróválasztó és választható joggal, illetve egyéb szerjárás szerinti jogokkal, mint a borkimérés, csak a sessiobirtokos polgárok rendelkeztek. ${ }^{67}$ A jogok mellett a kötelezettségek jogalapja úgyszintén a sessiobirtoklás volt, így a Kézai által is említett helyadó mellett, a vármegye ispánsági hadában való szolgálat, illetve az azt megváltó hadiadó teljesítése a 1112. századdal egyezően, még a 16. század közepén is a polgárok valálbeli közösségi jogviszonyán alapult, függetlenül a jobbágyi vagy zselléri szolgálatuk jellegétől, illetve a településük villa, oppidum vagy civitas jogállásától. ${ }^{68}$ Annak ellenére, hogy a valál jogintézményét gyakran, például a kötelezettségek megfizetése tárgyában egyszerü képzettársításként közönségesen csak falunak, vagy városnak írták, a valál mégsem jelentette kizárólagosan egyetlen település, egyetlen polgári közösségét. Gyakorta előfordult ugyanis, hogy két falu, más esetben egy város egy faluval, de akár 8 falurész együttesen alkotott egyetlen valált,

66 Kapuvári urbáriumokban részletesen leírták a valál adózását, különösképpen az 1584. és 1592. éviben, amelyekben a szolgálati mód mellett egyedülálló módon azt is beírták a sessiobirtokosoknál, hogy milyen jogviszony szerint birtokoltak. 1584-es MNL OL E 156 Fasc. 56. nr. 33., 1592-es MNL OL E 185 9. tétel nr 212., 1597-es MNL OL E 156 Fasc. 12. nr. 42.

67 A Trencsén megyei Beszterce oppidum 1506-ban kelt rendtartása a legszemléletesebb. Eszerint kizárólag a város 52 házát és a hozzátartozó helyföldeket birtokló polgárok bírtak választójoggal, közülük került ki a bíró, illetve az esküdtek: „In quolibet anno iudex et iurati solummodo de illis quinquaginta duobus eligantur et non aliis." A kertbeliek (ortulanus), avagy a zsellérek és az egyéb lakosok nem választhattak, sőt külön megtiltották nekik a városi gyűlésen vagy a tanácsüléseken való részvételt. Podmaniczky I. 246. A Zala megyei gelseiek 1565-ös panasza, miszerint a „falu velálul” fizette az ispán járandóságát, másként a két fogalmat szembeállítva, a település veláljának közössége és nem a falu egésze. MNL OL P 507 4. 4. 10. Újudvar és Zsigárd panasza: „az bírót kit tettek volt harmadéven velalul, le vonta róla és az velal ellen másra vetette és arrúlis el vonván harmadikra és ellenek tarcsja kit nagy kissebségnek tarcsja az velal és bíró tét emberek." Következésképp Újudvaron és Zsigárdon a besztercei polgárok közösségéhez hasonlóan a bírót a velál választotta, mégpedig külön „bíró tét” emberek. Választójoggal ez esetben is csak egy meghatározott csoport rendelkezett, akik a velálnak is tagjai voltak. MNL OL P 507 4. 4. 10.

68 A valál polgárai (zsellérek, jobbágyok) mind a hadbavonulást, mind a hadiadó megfizetését közösen teljesítették, az adóköteles jobbágyi helyek száma után. Szatlóczki 2019a. 24-36.; Kézai II. 1. amit leggyakrabban a közös bíróválasztás ténye után iudicatusnak, vagy villicatusnak írtak. ${ }^{69}$

Ezen a ponton érdemes ismét visszakanyarodnunk István király korához és a civitast alkotó polgárság árpád kori fogalmát ezúttal Kézai Simont segítségül híva értelmezni. A források tekintetében meglehetősen jól értesült, de mégis gyakran félremagyarázott Kézai ugyanis a műve végén a szolgarendű köznépi csoportok rövid leírása során, lényegében a civitasok létrejöttét és egyben a saját koráig tartó fejlődését is, az általa ismert hagyomány szerint meglepően pontosan írta le. Kézai a szolgák eredetéről szólva előadta, hogy Pannonia elfoglalásakor a magyarok az alávetett népek közül némelyeket magukkal vittek a hadba, míg másokat a sátraik körüli szolgálatra fogtak. Később Géza és István idejében a pápa megparancsolta, hogy a keresztény foglyokat régi szabadságukban tartsák, más szóval szabadítsák fel, de ez alól olyképpen adott felmentést, hogy a foglyok földet műveljenek, és abból éljenek, mint más keresztények. Ezért végül kiknek földjük nem volt, saját szándékukból béradásra vállalkoztak, amelyet uraiknak fizettek. A castrensesekről szólva pedig megjegyezte, hogy a pápa végül megengedte István királynak, hogy az általa megváltott foglyokat maga bírja, mi okból a király megváltotta a magyaroktól a foglyaikat, kik közül némelyeket a váraihoz rendelt szolgálatra. ${ }^{70}$ Mindebből világosan kitünik, hogy István király a szolgarendű foglyok vélhetően jelentős részének megváltotta a szabadságát, és közülük is némelyeknek bér fizetése ellenében földet adott a várak (szállássávok) belső területén, akik ahogy azt a Karthauzi Névtelen is írta, valálokat, azaz villakat alkotva polgárként letelepedtek és polgári közösségeket, másként civitasokat hoztak létre. Az újonnan létrejött közösségnek, pedig István, majd László és Kálmán királyok adtak törvényeket, hogy „... egy arányú törvénnyel élnének és egy arányú méltósággal bírják egymást." A keresztény polgárok egyetemét, úgymint a királyság egyik legfontosabb fundamentumát latinul Regia Civitasnak nevezték, mint ahogy az Szent István egyik dénárjának hátlapján is szerepelt. ${ }^{71}$ A magyar polgár szó, melynek köznyelvi átvétele a korai alakja szerint mind az ó-, mind a közép-felnémet nyelvi korszakban egyaránt elképzelhető, és amelyek időbeli határa éppen István király idejére esett, ugyanis a német burgare szóból ered..$^{72}$ Jelentése eredetileg, a latin castrenses szóval egyezően, olyan várhoz tartozó személy, aki annak földjét bírta.

69 Sopron megyei babótiak „velálul, Ordóval egyetemben” fizették az adót, másként két falu közösen alkotott egy valált. Az Ordóiak esetében külön kiemeli az irat, hogy nem jobbágyok, az összeírás szerint zsellér módra szolgáló polgárok. MNL OL E 185 9. tétel nr. 212. 22. folio. „Bechehel Zegedew sum sunt sub uno iudice” A kanizsai tartomány 1567-es urbáriuma, melyben mindegyikre akad példa. A nyolc falurész iudicatusa Hegyföld valálja volt. MNL OL E 156 fasc. 29. nr. 9. 16. folio.

70 Kézai II. 1. 3.

71 Zsoldos Attila a Regia Civitas fogalmát Esztergom váraként értelmezte, miszerint a felirat a „királyi vár” jelentéssel fordítható. Zsoldos 1998. 10.

72 A polgár szó jelentéséről és nyelvi átvételéről a 19-20. század fordulóján hosszas vita folyt, melynek kiváló összefoglalására lásd Mollay 1951. 21-35 
A magyar vár/váras és a latin civitas kifejezése bár nem ugyanazt jelentette, mégis a polgárok közössége nem létezhetett vár és annak földje nélkül. Hasonlóképpen egy esperesség aligha jöhetett volna létre egy szállássáv belső területén, ha ott civitas és benne tizedfizető szabad polgárok lakta valálok nem alakultak volna meg. Az ellentmondás éppen ebben rejlik, mivel számos olyan kisebb szállássávok határolta megye létezett, amelyekben önálló esperesség, és így vélhetően korai civitas alakult, viszont azokban várnak sem az írott, sem a régészeti forrásokban nyoma sincs. Ilyen (fő)esperesség volt például a már említett szeghalomi, Körösköz megye gyűrűs szállássávok határolta területével megegyezően. Éppen ezért felmerül annak a lehetősége, hogy az iráni eredetű vár szavunk elsődleges jelentése nem egy konkrét épület volt, hanem maga a gyepűvel védett szállássáv egésze, míg körül való határa, azaz a két szállássávot elválasztó megyéje (lat. közepe), a tulajdonképpeni belső terület. A vár szó középkori és mai jelentéséből azonban mindez csak nehezen magyarázható, mivel mindeddig fel sem merült annak lehetősége, hogy a magyarok az államalapítás előtt a nomadizáló életformájuk okán valaha is várakat, vagy városokat építettek volna. ${ }^{73}$ Mindazonáltal etimológiai szótáraink bár minden esetben közlik a szó iráni eredetét és általános eredetmagyarázatát, de legkorábbi formájában a középkori magyar történelemböl kiindulva, általában csak a földsánc, megerősített hely, erődítmény, vagy kastély jelentéssel ismertetik. ${ }^{74}$ Ezzel szemben a vár szavunk a honfoglalók nyelvébe vélhetően egy közép-északiráni nyelvből, jóval a 10. század előtt került át, és a uer igető valamely származékából főnevesült. Ennek jelentése pedig valamit körbe, körül fordul, fon, forog, tekeredik, avagy körbe, körül lezár, betakar, véd. ${ }^{75} \mathrm{~A}$ vár és az abból származó váras fogalma tehát vélhetően a 12-13. század előtt, elsődlegesen valamely védett hely vagy település körbe/gyürübe foglalását/lezárását jelentette, ami akár maga a szállássáv védelmi szerepe is lehetett, mégpedig annak építési módjától függetlenül, míg a nyugati hatásra leszükült „modern” vár és kastély értelme, későbbi fejlemény.

Szent István uralkodásának idejéből mindössze egyetlen interpolált formában fennmaradt oklevél szól civitasokról, mégpedig a veszprémi püspökség 1009re keltezet adománylevele. Ebben István király négy civitast, név szerint Veszprémet, Fehérvárt, Kolont és Visegrádot, azok minden egyházával, illetve határaikkal a veszprémi püspökség egyháza alá rendelte. Más szóval a megváltott és földhöz jutatott keresztény foglyok, illetőleg leszármazottaik által létrehozott keresztény polgárok közösségének egyházait, avagy egyházközösségeit, illetve azok területét és határait, avagy a hozzájuk tartozó filiákat, kápolnákat. ${ }^{76} \mathrm{~A}$ civitas ez esetben egyértelműen a közösséget jelenti, és bár annak lakhelyét területileg megyének mondták, az oklevélben

73 Ennek ellenére a középkortól napjainkig fennmaradt az eredeti általános értelem is, például a szekérvár kifejezésében, ami lényegében gyürüként körbefonódó védművet takar.

74 TEsz III. 1090

75 Pokorny I. 1951. 1160.

76 Érszegi 2010. 23-26. nem Veszprém, Fehérvár, Kolon, vagy éppen Visegrád vára, vármegyéje szerepel, hanem azon polgárok közössége, akiknek István király minden egyházát, avagy egyházközösségeit a veszprémi püspökségnek alá rendelte. ${ }^{77}$ István király, mint ahogy azt Kézai is sejteti bár jó példával járt elöl a civitasok létrehozásában és a várhoz szolgáló polgárok (magyarul várnépek) telepítésében, de a folyamat maga mégis lassan haladt. Jól jelzi ezt az a szembetűnő állapot, hogy mikor I. András 1055-ben a tihanyi apátságnak számos helyet adományozott, azok közül mindössze kettő, Gamás és Fadd volt villa, azaz valál. ${ }^{78}$ Úgyszintén csak két villa szerepel a zselicszentjakabi apátság 1061-ben kelt alapítólevelében, miközben abban mintegy 15 lakott helyet jegyeztek fel. ${ }^{79} \mathrm{~A} 11$. század közepén tehát még nagyon kevés villa, avagy letelepült polgári majorságokból álló település létezett, bár elvileg több falu polgárai is alkothattak egyetlen valált/villat, de így is a falvak többségében egyszerü, és nem helyhez kötött szállásokon (mansio) élő szolgálók lakhattak. Ennek tükrében kell értelmeznünk Szent István törvényeinek azon passzusát is, miszerint minden 10 valál építsen egy templomot. Mindezeket pedig lényegében a 11 . századi temetők lelőhelyei is megerősítik. A templom körüli temetők ugyanis akkor jöttek létre, mikor a birtokaik révén már helyhez kötött polgárok a törvények szerint templomot építettek. Nem csoda tehát, hogy a 11. századi soros temetők többségének általában a század közepéig, végéig keltezhető a használata, mivel a 11. század első felében a megtelepült valálok, és az abban létesült egyházak száma civitasonként bizonyosan elenyésző lehetett. Ugyanakkor a civitasok,

77 Zsoldos Attila széles körben elfogadott elmélete szerint Kolon civitas ekkor még Somogy és Zala megyét jelentette együttesen. Továbbá véleménye szerint Visegrád megye magába foglalta Pest megye Dunától keletre fekvő részét is. Zsoldos 2010. 8. A szállássávok és belső területeik rendszere, illetve a civitasok fentebbiek szerinti értelmezése azonban határozottan ellentmond mindkét elméletnek. Kolon jól azonosítható a Zala megyében, a szántó székkel megegyező szállássávi gyürü területével. Visegrád területe pedig egyértelműen nem lépte át a Dunát, valamint Pest gyürűjétől nagyrészt a nógrádi szállássáv és esperesség nyúlványa is elválasztotta a Duna túloldalán. A hivatkozott veszprémi adománylevélben éppen Úrhida civitas világit rá az ellentmondásokra amely önálló szállássávi gyürüvel bírt, valamint a birtokadományok olyan formában szerepelnek az oklevélben, hogy abból azt sem lehet eldönteni, hogy eredetileg is benne lettek volna. A 11. század első felében ugyanis egyetlen hiteles oklevélben sem nevezték meg a birtokok esetében, hogy melyik civitasban feküdtek, annál is inkább mivel az elsődlegesen nem vármegyét jelentett. $\mathrm{Ha}$ Úrhida már 1009-ben a veszprémi civitas része lett volna, akkor önálló területü civitasként, avagy közösségként sem értelmezhető az említése. Feltehetően az oklevél 13. századi szerkesztése során, a hitelesség látszata miatt feleltették meg a birtokokat az ismert civitasoknak, esetleg akkor kerültek bele kiegészítésként egy, vagy kettő másik korai oklevélből. Úrhida nyilvánvalóan nem volt sem vár, sem „várispánság”, sokkal inkább egy gyürüs belső terület saját polgári közösséggel és abból fakadóan esperességgel is. Az sem valószínü, hogy a civitasok már ekkor egyáltalán kiterjedtek volna a szállássávok területére. Véleményem szerint az oklevél egyedül hitelesnek elfogadható része a civitasok püspök joghatóság alá rendelése. A civitasok István uralkodásának idején vélhetően nem egyszerre és nem egy időben jöttek létre, továbbá mivel az alapító oklevél kelte is bizonytalan, számos magyarázat lehetséges arra, hogy mért csak 4 civitas szerepel benne.

78 Hoffmann 2010. 23-32.

79 Kumorovitz 1964. 43-83. 
másként a szállássávok határolta gyűrük belső területén nyitott 11 . századi nagy sírszámú soros temetők esetében valószínűnek tủnik, hogy a letelepített népesség már felszabadított és polgári jogállású volt, de valamely közelebbi valál részeként, még nem rendelkezett saját templommal. Ilyen lehetett a külső-somogyi civitas területén a kéri (Fiad-Kér puszta) temető népe, akik Szent László király uralkodásának idején, vagy nem sokkal azután hagytak fel a soros temetőjük használatával. ${ }^{80} \mathrm{Az}$ egykori foglyokból, letelepített polgárokká válás folyamata a nemesek uraságaiban még a királyi és egyházi kézben lévő területekhez képest is meglehetősen lassan történhetett, ugyanis a szállássávok közvetlen közelében, vagy annak területén lévő soros köznépi temetőket használták a legtovább, sok esetben a 12. század közepéig. ${ }^{81}$ Éppen ezzel hozható összefüggésbe Kézainak az udvarnokok eredetéröl szóló említése, miszerint még Kálmán király idejében is a nemesek egy számottevő része sok keresztény foglyot, lényegében rabszolgát tartott, amit azonban a király megtiltott, és azoktól, akik ennek nem engedelmeskedtek, elkobozták a foglyokat, majd a nádor birodalma alá rendelve - immár vélhetően polgárokhoz hasonlóan - szolgáltak tovább az ország és nemesei hasznára. ${ }^{82} \mathrm{~A} 12$. század elejére a szállássávok által határolt területek belsejében a királyok telepítő politikája révén, szinte minden falu valál lehetett, így a pannonhalmi apátság birtokainak Szent László király idejében készült összeírásában már villak szerepelnek, míg a regölyi területen birtokadományt kapó dömösi prépostág 1138-ban kelt adománylevelében úgyszintén. ${ }^{83}$ Ugyanakkor a szállássávok nemzetségi eredetű birtokain még Kálmán törvényei dacára is a szolgálók többsége nemesi jószágokon (praedium) élt földtulajdon és polgárjog nélkül. Az almádi apátság 1121. évi alapítólevelében az Atyusz nemzetség által adományozott, és a két Páka kivételével a zalai, veszprémi és somogyi szállássávokba eső 20 birtokból még egy sem volt valál, ellenben 18-at nemesi jószágként, 2-öt pedig egyszerü helyként írtak össze. Mindazonáltal határos szomszédként kizárólag valálokat említettek, amiből a többség már a belső területek szélén feküdt, mint a zalai Zsid vagy Tomaj. Megjegyezendő ugyanakkor, hogy 6 jószágon már akadtak szabadosok, 2 helyen templom, illetve Kispákán két cenzust fizető hospes is. A szolgálók letelepítése tehát már megindult az Atyusz nemzetség birtokain, épültek templomok és akadtak felszabadított szabados és hospes polgárok is, de valált még egyet sem alapítottak. ${ }^{84}$

De hogy ez a társadalmi folyamat még a 14. század derekáig is eltartott, azt jól mutatják az oklevelekben később is sűrűn, főként a szállássávokon előforduló valál nélküli szolgáltató praediumok és Kézai azon megjegyzése, hogy Istvántól fogva egészen az ő koráig, mindez csak a keresztény eredetű foglyok-

80 Hegyi-Varga 2015. 2.

81 A soros temetőkből ismert legfiatalabb pénzérmék II. Béla idejéből (1131-1141) származnak. Révész 2018. 24.

82 Kézai II. 2.

83 Wenzel VI. 220.; Mon. Eccl. Strig. I. 88-97. (65.)

84 Szentpétery 1927. 360-370. ra és leszármazottaikra volt érvényes, mert a pogány népekből származók esetében a pápa megengedte, hogy azok a keresztény uraiknak alávetve maradjanak. Kézai szerint - még a saját korában is - őket nevezték magyarul Uhugnak. ${ }^{85}$

Végezetül tisztázni kell azt a kérdést, hogy a 10-12. századi társadalom mely elemekből állt össze és abban hol foglaltak helyett a szolgák és a belőlük kialakuló szabad polgárság. A válasz egyszerü, bár első ránézésre a források tükrében meglehetősen bonyolultnak tűnik. Ennek oka elsősorban a polgárságra/várnépekre és a zsellérségre fennmaradt iratanyag egyoldalúsága, miszerint végig a középkoron át az ignobilis jogállású embereket, szinte minden esetben az uraságaik számára fontos szolgálati rendtartásuk megnevezésével jegyezték fel. Így a 11-13. századi törvényekben és oklevelekben is jobbágyokról, vitézekről, szolgákról, szabadosokról, udvarnokokról, kondicionáriusokról és a szolgáltató népek megannyi szolgálati formájáról/ módjáról olvashatunk, de csak ritkán került feljegyzésre az egyes szolgálói csoportok valós társadalmi jogállása. A szolgálati állapot (status) - ahogy egyébként végig a középkoron át - ugyanis nem azonos a szabadok és nem szabadok, illetve a „birtokosok” és birtoktalanok jogi állapotával. A szolgálatot vállaló szabad ember, polgár, vagy nemes jobbágy, ugyanis csak a szolgálatában és az azt eltartó ingó jószágai tekintetében tartozott az ura, avagy az ispán bírói hatalma alá. Ebbéli önként vállalt, vagy öröklött szolgálatában tehát nem volt szabad, ha ugyanis azt nem teljesítette, vagy megszökött, akár a személyi szabadságában is korlátozható volt. Ettől persze önmagában nem vált „félszabaddá”, hiszen ezen ismérvek szerint a középkori nemes familiárisok tömege sem lett volna szabad ember. Ellenben a szabad jogállású, de szolgálatában akár örökletesen kötött személy a szolgálata ideje alatt mindvégig, a szerzett, vagy öröklött ingó és ingatlan jószágairól szabadon rendelkezhetett, tehát a köteles szolgálatától függetlenül magánjogi értelemben szabadnak számított. 86

A korabeli magyar társadalomnak ugyanakkor sem a polgárság, sem az abból kirekesztődött földnélküli szabadok - a későbbi zsellérség ősei - nem voltak a részei. ${ }^{87}$ Különösképpen nem volt az a 13-14. század fordulójára eltűnő, személyében nem szabad, szolgálói réteg. Egyrészről az eredetükre nézve nem rendelkeztek szabadsággal, másrészről annak elnyerése után sem váltak a nemesi ország részéve, hanem külön közösségekbe szerveződtek, amelyek továbbra is a nemesség vezető rétegének bírói közhatalma alatt álltak. Másodsorban ebböl fakadóan külön törvényeket kaptak, illetve a szabadsággal elnyert birtokigazságukból fakadó hadviselési kötelezettségüket is a nemesekétől eltérő szervezetben teljesítették. Az ország fogalmába ugyanis a szó alapjelentésének megfelelően, vélhető-

\footnotetext{
85 TEsz III. 1028. Kézai II. 7.

86 Holub 1929. 49

87 A zsellér a szó jelentése szerint házal rendelkező szabad ember, a polgártól eltérően azonban nem rendelkezett ingatlan igazsággal, így a háza is másnak a földjén épült.
} 
en már a 10. századtól csak az uruszágok/uraságok összessége tartozott bele, így az országlakosok kifejezés tartalma alatt is pusztán a későbbi nemességet értették. A mai fogalmaink szerinti „társadalom” tehát két, élesen elkülönülő csoportból állt, amelyek külön közösséget alkottak és köztük csak különös királyi kegy - nemesség és birodalom adományozása - révén nyílt alkalmi átjárás. ${ }^{88} \mathrm{~A} 10$. századi ország közösségét e képen a honfoglaló szabad népesség egésze, míg a 11. századtól az ő leszármazottjaik és a királyi kegy révén a nemesek közé, avagy az országba, mint közösségbe befogadott közönséges származásúak és idegen jövevények alkották. A régészettudomány által mesterségesen meghatározott un. „köznép” ily módon az ország 10-11. századi társadalmának, mint közösségnek, sem része, sem bárminemü jogviszonnyal rendelkező köznépe nem volt! Látszólag az egyetlen kivételt csupán azok a hagyomány szerint már a 11 . századtól megjelenő és egy-egy településre szorítkozó szabad királyi civitasok (pl. Fehérvár) jelentették, amelyek többnyire hospes eredetű polgárai a szabad bíróválasztás és ítélkezés kiváltságával, a 14-15. századtól kezdve a törvények és a rendek által is elismert módon (lényegében az ország közösségébe befogadva) ispáni közhatalmat nyertek, azonban azt nem egyénenként, hanem mint közösség bírták. ${ }^{89}$

Ellenben a honfoglalók társadalma önmagában is két részből állt, lévén megvolt a maga közönséges, saját urasággal nem bíró, csak a szolgái személyét és talpalatnyi szállását (sessio/curia nobilitaris) magáénak tudó, többnyire az uraiknak szolgáló, de szabad jogállású köznépe, másként a későbbi királyi szerviensek, a kis- és egyházhelyes nemesség ősei. Az egyházhelyes nemesek ugyanis az ország közösségén belül alapvetően elkülönültek, mind a civitasok szabad jogállású csoportjától, mind az uraságot/ispánságot tartó (veláltartó, homo possessionatus) nemesektől, aszerint, hogy urasággal, másként ispáni/bírói közhatalommal és az azt eltartó birodalommal (possesio) nem bírtak, udvarhelyeiken csak zsellérek éltek, így szolgáló jobbágyokkal sem rendelkeztek. Megkülönböztette őket maga a nemes szó is, amely eleinte csak az urakra vonatkozott, lévén eredetileg azon nemmel/ nemzetséggel rendelkező embert jelentette, aki úrsága jogalapját, az azt szerző őse nemzetéből vezette le. ${ }^{90}$ Bár hagyományaik szerint Szent István is meghagyta a szabadságukat, és nem kényszerítette őket az ispánok és a civitasok kötelékébe, de a nemzetségi eredetű uraságot bíró nemesekkel és a királyi adományosokkal, végül csak 1267-ben lettek a törvények szerint is teljesen egyenjogúak. ${ }^{91} \mathrm{~A}$ hétköznapokban azonban a nemesség két rétege sosem vált egyenrangúvá, hiszen az uraságok túlnyomó többségét továbbra is a nemzetségekből származó, vagy velük rokonságba került családok bírták. Számarányuk az uraságot tartó réteghez képest vélhetően viszonylagosan állandó maradt a 10. századtól végig a középkoron át, bár jóval nagyobb arányban kerültek közéjük beházasodás útján ignobilis polgári származásúak. A legnépesebb egyházhelyes nemesi közösségekkel bíró 16 . századi Vas és Zala megyékben, a 300-400 uraságot tartó nemesi családföre, mintegy 1000-1300 közönséges nemes jutott.92 Az „ország” két nemességének egymáshoz való arányát a 10-11. században csak becsülni lehet, bár éppen a szállási temetők sírszámai alapján, hasonló, 3-5-szörös arányok mutatkoznak, mint a középkorban.

Végezetül megjegyezendő, hogy a régészeti terminológia által meghatározott tárgyi hagyatékból jól elkülöníthetően, és közvetlenül eredeztethető az államalkotó ország, másként a szabadok (nemesek) közössége, illetve attól külön a rabszolga jogviszonyú alávetett népességböl a hosszas folyamat végeredményeként a 14. századra egységesülő közönséges szabad polgárság és zsellérség. Ennél fogva pedig a 10. századi honfoglalók szabad társadalmának az un. „köznépi” temetők népe nem tekinthető egyenjogú tagjának, másként jogviszony szerint a magyar „törzsszövetség” „államalkotó” részének sem! Ebböl pedig egyenesen következik, hogy a 10-11. századi társadalmi folyamatok eredményeként egy „etnikailag” és nyelvileg egységes honfoglaló csoportból, nem jöhetett volna létre egy egymástól elkülönülö, hármas tagolódású társadalomszerkezet, márpedig a honfoglalók régészeti hagyatéka és az írott források ez utóbbit mutatják.

\section{Irodalom}

BÁNDI Zs. 1986: A szakácsi pálos kolostor középkori oklevelei. - Somogy megye múltjából 17. Kaposvár 1986. 27-65

BÁRDos E. 1991: Somogyjád-Gépállomás, honfoglaláskori temető. In: Régészeti Füzetek 1/43. Budapest 1991. 41.

BORSA I. 1998: A somogyi konvent oklevelei az Országos Levéltárban. - Somogy megye múltjából 29. Kaposvár 1998. 3-40.

BotKA T. 1872: A vármegyék első alakulásáról és őskori szervezetéröl. Negyedik közlemény. - Századok 6. Pest 1872. 23-38.
Budenz J. 1874: Valal (Valál). - Magyar Nyelvőr 3. Budapest 1874. 291-292.

Corpus StATUtorum I.: Corpus Statutorum Hungariae Municipalium I. A magyar törvényhatóságok jogszabályainak gyűjteménye I. Az erdélyi törvényhatóságok jogszabályai. Kolosvári Sándor, Óvári Kelemen. Budapest 1885

ENGEL P. 2001: Magyarország a középkor végén: digitális térkép és adatbázis. Szerk.: Engel Pál. Budapest 2001.
88 Tripartitum 1611. 16.

89 A 14. századra számos civitas elnyerte az ispáni közhatalmat, azonban többségük esetében az megmaradt a királyi birtokigazgatás tartományi ispánsági kereti között, így eladományozásukkal végképp megrekedtek a jogi fejlődés útján. Tripartitum 1611. 463-465.
90 Györffy 1959. 15.

91 A királyi szerviensekre lásd Szücs 1984. 341-394

92 1549-ben a Vas megyei rovásadó szerint 266 veláltartó és mintegy 1000 fö egyházhelyes családfö élt, míg Zalában 380 veláltartóra, kb. 1300 egyházhelyes jutott. Szatlóczki 2019a. 18. 
ÉRSzEGI G. 2010: I. (Szent) István veszprémi adománylevele. - In: Tanulmányok a veszprémi egyházmegye történetéröl. - A Veszprém Megyei Levéltár Kiadványai 22. Veszprém 2010. 9-32.

ETE V.: Egyháztörténelmi emlékek a magyarországi hitújítás korából V. 1548-1551. Szerk. Karácsonyi János, Kollányi Ferenc, Lukcsics József. Budapest 1912.

GuLYÁs L. Sz. 2016: A középkori Szatmár megye egyházi intézményei. - In: A történeti Szatmár vármegye I. Nyíregyháza 2016. 155-180.

GYÖRFFY GY. 1959: Tanulmányok a magyar állam eredetéröl. A nemzetségtöl a vármegyéig, a törzstöl az országig. Kurszán és Kurszán vára. Budapest 1959.

HEGYI B. ÉS VARGA M. 2015: Somogy megye 10-11. századi temetőinek és sírleleteinek kutatása. - In. Magyar Régészet Online 2015. Tél. 1-8.

HofFMANN I. 2010: A Tihanyi alapítólevél mint helynévtörténeti forrás. A Magyar Névarchívum Kiadványai 16. Debrecen 2010.

HoluB J. 1929: Zala megye története a középkorban I. A megyei és egyházi közigazgatás története. Pécs 1929.

HoRVÁTH R., NEMES G. És VAJK Á. 2019: Győr város polgárai a középkorban 13. sz. - 1526. - Győri Tanulmányok 40. 2019. 153-196.

KARÁcsONYI J. 1900: A magyar nemzetségek a XIV. század közepéig I. Budapest 1900.

KARÁcsonYI J. 1901: A magyar nemzetségek a XIV. század közepéig III. Budapest 1901.

KARTHAUZI 1859: Magyar Szentek legendái a Carthausi Névtelentöl. Szerk. Toldy Ferenc. Pest 1859.

KÉZAl: Kézai Simon mester krónikája. Ford. Szabó Károly. Pest 1862.

Komjáthy M. 1973: A somogyi konvent II. Ulászló-kori oklevelei az Országos Levéltárban. - Somogy megye múltjából 4. Kaposvár 1973. 45-54.

KöLTő L. 1993: Honfoglalás kori tegezes sír Vörsön. - A Herman Ottó Múzeum Évkönyvei 30-31/2. Miskolc 1993. 433-443.

Költő László és Szentpéteri József 1996: A Vörs-Papkert „B” lelőhely VIII-XI. századi temetője. - In: Évezredek üzenete a láp világából. Régészeti kutatások a Kis-Balaton területén 1979-1992. Kaposvár-Zalaegerszeg 1996. 115-122.

KöLtő L. És VARGA M. 2019: Kaposvár és környéke az avar korban és a kora Árpád-korban. - Hadtudományi Szemle XII. Budapest 2019. 177-200.

KRISTÓ GY. 1988: A vármegyék kialakulása Magyarországon. Budapest 1988.

Kumorovitz L. B. 1964: A Zselicszentjakabi alapítólevél 1061-ből. („Pest” legkorábbi említése). - Tanulmányok Budapest Múltjából XVI. Budapest 1964. 43-83.

LANGÓ P. És SıKLósı Zs. 2013: 10. századi temető Balatonújlak-Erdődülőn. - In: A Honfoglalás kor kutatásának legújabb eredményei. Tanulmányok Kovács László 70. születésnapjára. Monográfiák a Szegedi Tudományegyetem régészeti tanszékéről 3. Szerk. Révész László, Wolf Mária. Szeged 2013. 143-160.

LIBER SANCTI, J. 2005: Liber Sancti Johannis Capituli Agriensis. Az egri káptalan Szent János könyve. - In: Az Egri Egyházmegye történetének forrásai 9. Eger 2005.

Mollay K. 1951: Szójegyzékeink polgár szava. - Magyar Nyelv 47. Budapest 1951. 21-35.
MoN. Eccl. Strig. I.: Monumenta Ecclesiae Strigoniensis. Tomus primus. Ferdinandus Knauz. Esztergom 1874

NÉMETH P. 1990: A szabolcsi föesperesség a középkorban. - Szabolcs-Szatmári Szemle XXV. 2. Nyíregyháza 1990. 133-149.

PÁPAl 1708: Dictionarium latino-hungaricum. Francisco Pariz Pápai. Leutschovieae [Lőcse] 1708.

PATAY P. 1963: Bihardancsháza. - Régészeti Füzetek 15. Budapest 1963. 56.

PESTY F. 1880: Az eltünt régi vármegyék I. Budapest 1880.

PESTY F. 1882: A magyarországi várispánságok története különösen a XIII. században. Budapest 1882.

PodmANICZKY I.: A pormanini Podmaniczky-család oklevéltára I. 13511510. Közli: Lukinich Imre. Budapest 1937.

POKORNY, J. 1951: Indogermanisches etymologisches Wörterbuch I. Bern, Müchen 1951. Online: https//indogermanische.org. (letöltve: 2020. május 20.)

RÉVÉsz L. 2018: A 10-11. századi temetők regionális jellemzői a Keleti-Kárpátoktól a Dunáig. Szeged 2018. [Akadémiai doktori értekezés]

SchemATISMUS 1896: Schematismus Historicus Venerabilis Ceri Diocesis Magno-Varadiensis Latinorum. Nagyvárad 1896. [Hasonmás kiadás. Nagyvárad 2010.]

SZATLÓCZKI G. 2019a: A magyar vármegyei és vártartományi hadszervezet a 16. század közepén. Az 1550. évi dunántúli őszi hadfelKELÉs. - GYŐRI TANULMÁNYOK 40. GYÖR, 2019. 7-38.

SZATLÓCZKI G. 2019b: A honfoglalás kori gyepű. (Az egyházhelyes nemesek és nyugat-dunántúli településterületük). - „ugy irhassok mint volt”. Ünnepi tanulmányok a 65 esztendős Tóth Sándor László tiszteletére. Fontes et Libri 2. Szeged 2019. 68-93.

SzENTPÉTERY I. 1927: Az almádi monostor alapító oklevele II. István korából. - Magyar Nyelv XXIII. 3-6. Budapest 1927. 360-370.

Szűcs Jenő 1984: Az 1267. évi dekrétum és társadalmi háttere. Szempontok a köznemesség kialakulásához. - In: Mályusz Elemér Emlékkönyv. Szerk. H. Balázs Éva, Fügedi Erik, Maksay Ferenc. Budapest 1984. 341-394.

Szűcs J. 1993: Sárospatak kezdetei és a pataki erdőuradalom. - Történelmi Szemle XXXV. 1-2. Budapest 1993. 1-57.

TAKÁTS S.1906: Valál. - Magyar Nyelv 2. Budapest 1906. 76.

TEsz III.: A magyar nyelv történeti-etimológiai szótára III. Ö-Zs. Szerk.: Benkő Lóránd. Budapest 1970.

THOROCZKAY G. 2002: Szent István pannonhalmi oklevelének kutatástörténete. - In: Szent István és az államalapítás. Szerk. Veszprémy László. Budapest 2002. 237-263.

TRIPARTITUM 1611. - Decretvm iuris consuetudinarii inclyti Regni Hungariae et Transylvaniae. Az az Magyar és Erdély Országnak Törvény könyve. Verbőci István által iratot 1514. esztendőben. Debrecen 1611.

WENZEL VI.: Árpádkori új okmánytár. Codex diplomaticus Arpadianus continuatus VI. Köz.: Wenzel Gusztáv. Budapest 1867.

Zsoldos A. 1998: Visegrád vármegye és utódai. - Történelmi Szemle XL. Budapest 1998. 1-32.

Zsoldos A. 2010: Korai vármegyék az újabb történeti kutatások fényében. - Castrum 11. Budapest 2010. 5-14. 